\title{
The Late Ordovician glacial sedimentary system of the North Gondwana platform
}

\author{
JEAN-FRANCOIS GHIENNE*, DANIEL PAUL LE HERON*广, JULIEN MOREAU*, \\ MICHAEL DENIS $\ddagger$ and MAX DEYNOUX* \\ *Ecole et Observatoire des Sciences de la Terre, Centre de Géochimie de la surface, CNRS-UMR 75I7, I rue Blessig, \\ 67084 Strasbourg, France (e-mail: ghienne@illite.u-strasbg.fr) \\ tPresent address: CASP, Department of Earth Sciences, University of Cambridge, West Building, I8IA Huntingdon Road, CB3 ODH, UK \\ ‡UMR 556I, Biogéosciences, Université de Bourgogne, 6 Bd Gabriel, 21000 Dijon, France
}

\begin{abstract}
The Late Ordovician (Hirnantian) glaciation is examined through the North Gondwana record. This domain extended from southern high palaeo-latitudes (southeastern Mauritania, Niger) to northern lower palaeo-latitudes (Morocco, Turkey) and covered a more than $4000 \mathrm{~km}$-wide section perpendicular to ice-flow lines. A major mid-Hirnantian deglaciation event subdividing the Hirnantian glaciation in two first-order cycles is recognised. As best illustrated by the glacial record in western Libya, each cycle comprises 2-3 glacial phases separated by ice-front retreats several hundreds kilometres to the south. From ice-proximal to ice-distal regions, the number of glacial surfaces differentiates (i) a continental interior with post-glacial reworking of the glacial surfaces), (ii) a glaciated continental shelf that is subdivided into inner (I-2 surfaces), middle ( $2-5$ surfaces) and outer (a single surface related to the glacial maximum) glaciated shelves, and (iii) the non-glaciated shelf. Ice-stream-generated glacial troughs, $50-200 \mathrm{~km}$ in width, cross-cut these domains. These troughs are zones of preferential glacial erosion and subsequent sediment accumulation. A glacial depositional sequence, bounded by two glacial erosion surfaces, records one glacial phase. The position either within or outside a glacial trough controls the stratigraphic architecture of a glacial sequence. Glaciomarine outwash diamictites are developed at or near the maximum position of the ice-front. During ice-sheet recession, and in an ice-stream-generated trough, a relatively thin sediment cover blankets the foredeepened erosion surface. An initial rapid ice-sheet withdrawal is inferred. Marine-terminating ice fronts then evolve later into more slowly retreating, land-terminating ice fronts. In adjacent inter-stream areas where a more gradual ice-sheet recession occurred, fluvioglacial deposits prevailed. The progradation of a delta-shelf system, coeval with fluvial aggradation, that may be locally interrupted by a period of isostatic rebound, characterises the late glacial retreat to interglacial conditions. This model should facilitate the sequence stratigraphic interpretation of Late Ordovician glacial deposits and other ancient glacial successions.
\end{abstract}

Keywords Glacial record, Hirnantian, North Africa, ice stream, sequence stratigraphy.

\section{INTRODUCTION}

The Late Ordovician glacial record comprises extensive exposures distributed over the former North Gondwana cratonic platform. The size of this domain is $>1500 \mathrm{~km}$ from south to north (in present-day coordinates), and extended from Mauritania to Arabia. Southern regions were positioned near the ice centres while the northern part of the platform was located at lower palaeolatitudes (Fig. 1). During the 1960s-1980s, studies in Morocco (Destombes, 1968a, Hamoumi, 1988), Algeria (Beuf et al., 1971), Libya (Klitzsch, 1981; Massa, 1988), Mauritania (Deynoux, 1980; 1985; Deynoux \& Trompette, 1981) and Arabia (McLure, 1978; Vaslet, 1990; McGillivray \& Husseini, 1992) 

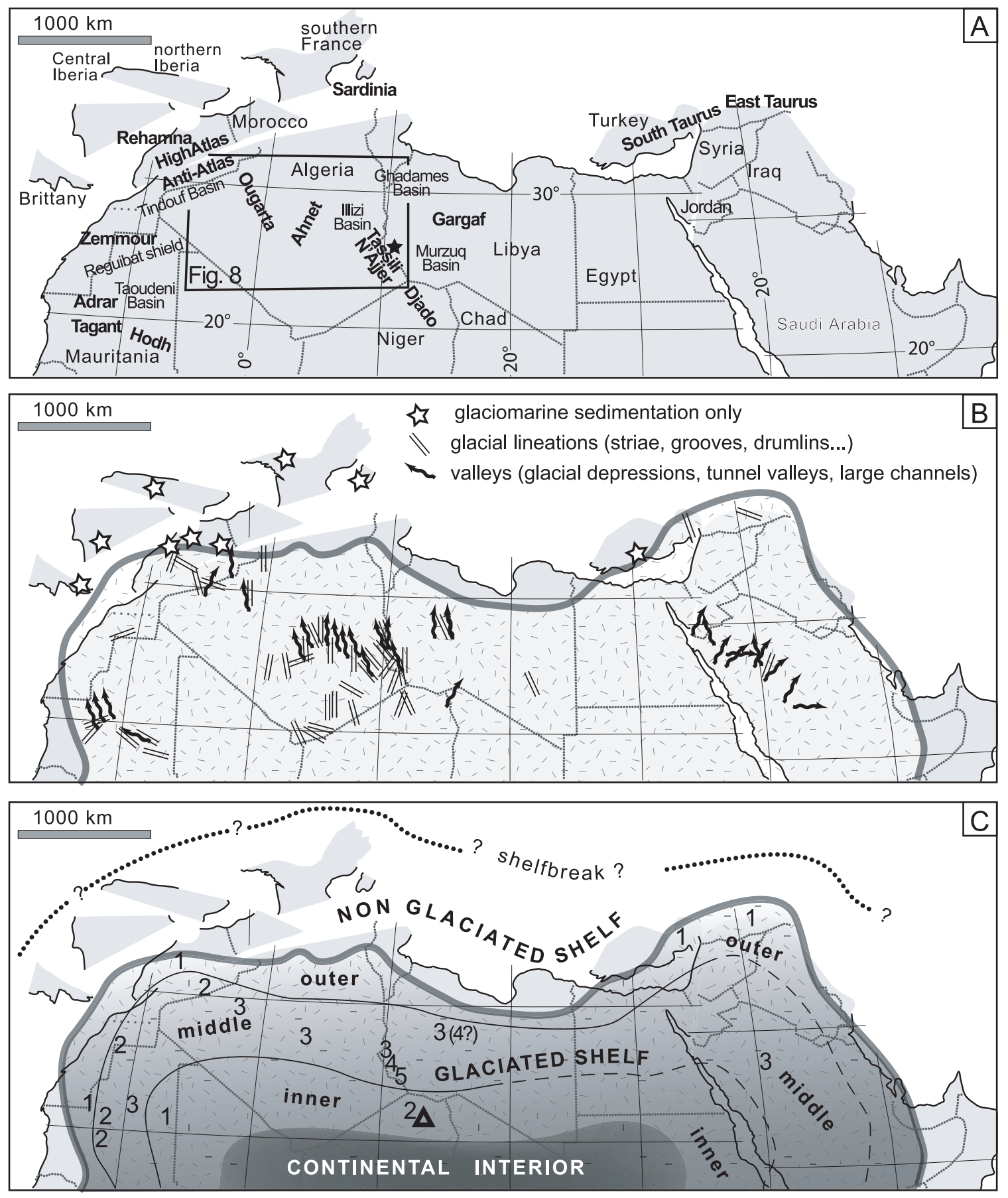

Fig. 1 The North Gondwana platform during the Hirnantian glacial event. (A) Main names cited in the text (see also Fig. 8). Names in bold indicates study areas comprising the data base. The black star locates the pre-glacial (Late Ordovician) trilobite-bearing lonestone found within the syn-glacial strata. (B) Location of areas that experienced grounded ice (glacial lineations and palaeovalleys) and those that have never been glaciated (glaciomarine sediments only). The outlined surface corresponds to the envelope of the ice fronts during the Hirnantian glacial maximum (modified from Deynoux \& Ghienne, 2004). (C) Subdivisions of the glaciated platform in five domains (name in bold) based on the number of glacial surfaces preserved. The location of the shelfbreak (continental margin) is not known but was located to the north of the study area, beyond the maximum ice fronts. The $\Delta$ locates mid-Hirnantian graptolite-bearing marine facies in the Djado area, suggesting the marine limit of the associated deglaciation was located to the south of this point. 
showed the extent, diversity and complexity of the syn-glacial strata. Renewed interest arose in the 1990s, when oil companies recognised the association of syn-glacial strata (reservoir rocks) with lower Silurian shales (source rocks) as one of the most significant plays in the North African Lower Palaeozoic succession (Lüning et al., 2000). Recent work has included detailed field and subsurface studies conducted in Mauritania (Ghienne, 1998; Ghienne \& Deynoux, 1998; Ghienne, 2003), Morocco (Ouanaimi, 1998; Sutcliffe et al., 2000, 2001; Le Heron et al., in press, a), Algeria (Hirst et al., 2002; Eschard et al., 2005), Niger (Denis et al., submitted), Libya (McDougall \& Martin, 2000; Smart, 2000; Ghienne et al., 2003; Le Heron et al., 2004; El-ghali, 2005; Moreau, 2005), Jordan (Abed et al., 1993; Powell et al., 1994; Turner et al., 2005), Saudi Arabia (Senalp \& Al-Laboun, 2000) and the Horn of Africa (Ethiopia and Eritrea, Kumpulainen, 2005). In addition to these areas, studies have also been undertaken around the northern Gondwana periphery to better provide an overall understanding of the glacial record as a whole, e.g. in Sardinia (Leone et al., 1995; Ghienne et al., 2000) and in Turkey (Monod et al., 2003).

This paper proposes a large-scale reconstruction of the North Gondwana platform in present-day North and West Africa during the Late Ordovician glaciation. The number of glacial advance-retreat events recorded from the near-polar ice centre to lower palaeo-latitudes, and the presence or absence of ice-stream tracks, are used to subdivide the platform into a number of domains characterised by a specific palaeo-glaciological evolution, particularly subglacial processes, stratigraphic architecture and depositional environments. Finally, a conceptual glacial depositional sequence that could be expected within a typical glacial advance-retreat event is depicted. Such a sequence will form the basis for a more robust stratigraphic analysis of the Late Ordovician glacial record and more generally for ancient glacial successions.

\section{PRE-GLACIAL SETTING}

No evidence for Late Ordovician glacial sediments older than Hirnantian (Fig. 2) has thus far been found in North or West Africa. However, this does not preclude the possibility that glaciers grew

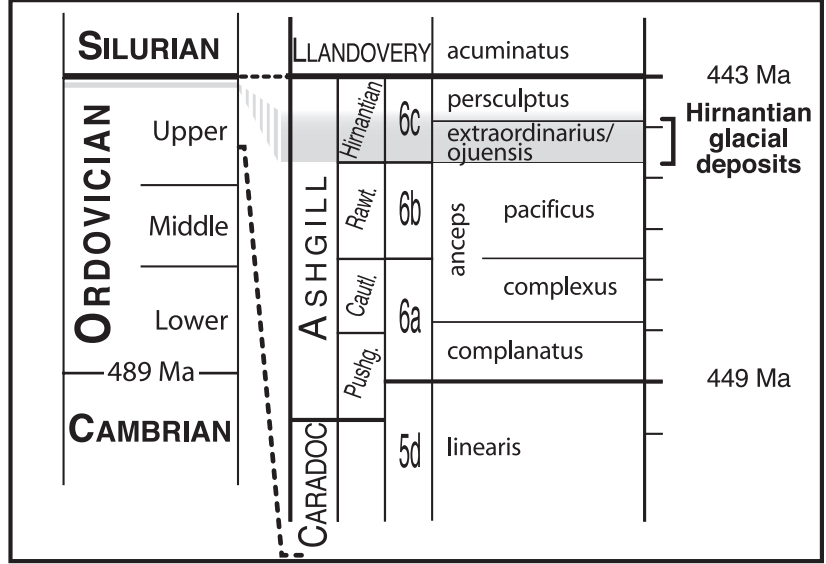

Fig. 2 Late Ordovician stratigraphic chart modified from Webby et al. (2004) showing the time range corresponding to Hirnantian glacial event.

elsewhere on Gondwana both before and after the Hirnantian. Saltzman \& Young (2005) proposed a glacio-eustatic lowstand during the early Late Ordovician (Fig. 2) and, in South America, glacial deposits are recognized in the Silurian (Grahn \& Caputo, 1992; Caputo, 1998). Ghienne (2003) suggested that the Hirnantian simply reflected a continent-wide ice maximum, during which ice sheets reached the North and West African sedimentary basins where their glacial sedimentary record could be preserved. In this paper, preglacial time is defined as the period preceding the Hirnantian, i.e. the Cambrian and Ordovician, including the main part of the Ashgill with the exception of the Hirnantian (Fig. 2). Le Heron et al. (2005) published a schematic lithostratigraphic summary of Hirnantian glaciogenic rocks across Africa and Arabia. A regional correlation scheme, including the names of the main preglacial and glacial formations in this huge region, is contained therein.

\section{Geological setting}

Late Ordovician glacial deposits rest on a Cambrian to Ordovician, clastic-dominated succession that has an off-shelf gradient towards the NNW (Boote et al., 1998; Carr, 2002). These sediments progressively buried palaeorelief forms associated with both the late Neoproterozoic Panafrican Orogeny and Cambrian post-orogenic collapse/strike-slip basins. Early Ordovician tectonic activity uplifted 
large areas such as the Taoudeni Basin and Reguibat shield, Central Algeria, Ahnet, Eastern Tassili and southern Taurus (e.g. Beuf et al., 1971; Crossley \& McDougall, 1998) (for location names, see Fig. 1A), resulting in deep erosion of earlier strata or reduced sedimentation on the highs during the Middle to Late Ordovician. Continuous sedimentation occurred in subsiding areas, e.g. the Tindouf Basin and Ougarta in Algeria, Ghadames Basin in Libya, eastern Taurus in Turkey. Here, a complete Ordovician succession is preserved (e.g. Boote et al., 1998). High eustatic sea level in the Late Ordovician (Ross \& Ross, 1992) resulted in the flooding of previously uplifted areas (e.g. easternmost Turkey, Dean \& Monod, 1990). In Algeria, shallow-marine Ashgill facies are known in the south of the Ougarta Range (Legrand, 1985) and Ashgill carbonates are identified in drill holes as far south as the Illizi Basin (e.g. Oued Ahara borehole, unpublished data). In SW Libya, some dropstones in glaciomarine facies include trilobites (located in Fig. 1A), yielding an age close to the Caradoc-Ashgill boundary (W.T. Dean, pers. comm., 2003). These fauna, which probably derived from higher southern polar palaeolatitudes, imply a southwards-directed Late Ordovician transgression, which penetrated far south onto the platform. Transgressive deposits have been difficult to recognise owing to glacially related erosion, but are herein considered as key evidence for the flooding of the main part of the North Gondwana platform prior to the Hirnantian glacial event.

\section{Subglacial substrate}

As a consequence of this pre-glacial flooding, it is clear that a large part of the glaciated areas should have been characterised by subglacial soft-sediment conditions. If Ashgill siliciclastics were not lithified in Hirnantian time, it is surprising that much older deposits were also very poorly lithified at that time, as suggested by three sets of observations: sand injections, cross-sections of palaeovalleys and a sand-dominated glacial record. Firstly, sand injections in the form of pipes or undulating dykes occur beneath glacial erosion surfaces cut in sediments as old as Early Ordovician (>30 Ma before the Hirnantian glacial event) in the western Murzuq Basin. Secondly, cross-sections of palaeovalleys, either subglacially or fluvially formed, show low-angle margins, with slopes typically in the $1-10^{\circ}$ range. These gradients are more compatible with erosion in soft material than in consolidated sediments. In addition, in the Ahnet area (south Algeria, Fig. 1A), palaeovalleys have a flat bottom coinciding with the basal unconformity of the Cambrian-Ordovician succession above the slightly metamorphosed late Neoproterozoic shales and sandstones. This suggests a clear contrast between the underlying metamorphosed basement and the overlying non- to poorly lithified sandy succession. Thirdly, the Late Ordovician glacial record is sand-dominated, with subordinate finer-grained, silt-dominated units Glacial conglomerates contain clasts from Precambrian basement lithologies (granites, metasediments e.g. quartzite), but not from the underlying Cambro-Ordovician sandstones (Oujeft sandstones in Mauritania, Hamra Formation in Algeria, Ash Shabiyat or Haouaz formations in Libya), which can be recognised by abundant Scolithos burrows. Notwithstanding small inliers of crystalline basement or rare carbonate-cemented Ordovician strata, the evidence presented above suggests that Late Ordovician ice sheets grew and decayed on largely unconsolidated substrates.

\section{RECOGNITION OF GLACIAL EROSION SURFACES}

In the sand-dominated setting of the Late Ordovician glacial record, depths of glacial erosion range from 10 to $500 \mathrm{~m}$ (maximum erosion depths in Saudi Arabia, e.g. McGillivray \& Husseini, 1992), and widths of glacially-cut depressions range from $10 \mathrm{~m}$ to $>100 \mathrm{~km}$. Erosional features form lineations, ovoid to elongated spoon-shaped depressions, straight to slightly sinuous channels and palaeovalleys, or basin-scale incisions. Criteria used to distinguish glacial erosion surfaces from fluvial or transgressive wave-ravinement surfaces include: large-scale morphologies, glaciotectonic structures and specific depositional features such as esker structures.

Depths of erosion greater than $100 \mathrm{~m}$ normally point towards subglacial processes (Fig. 3). If the erosion feature is relatively narrow $(<5 \mathrm{~km})$, tunnel valleys are inferred (Ghienne \& Deynoux, 1998; Hirst et al., 2002; Le Heron et al., 2004) 

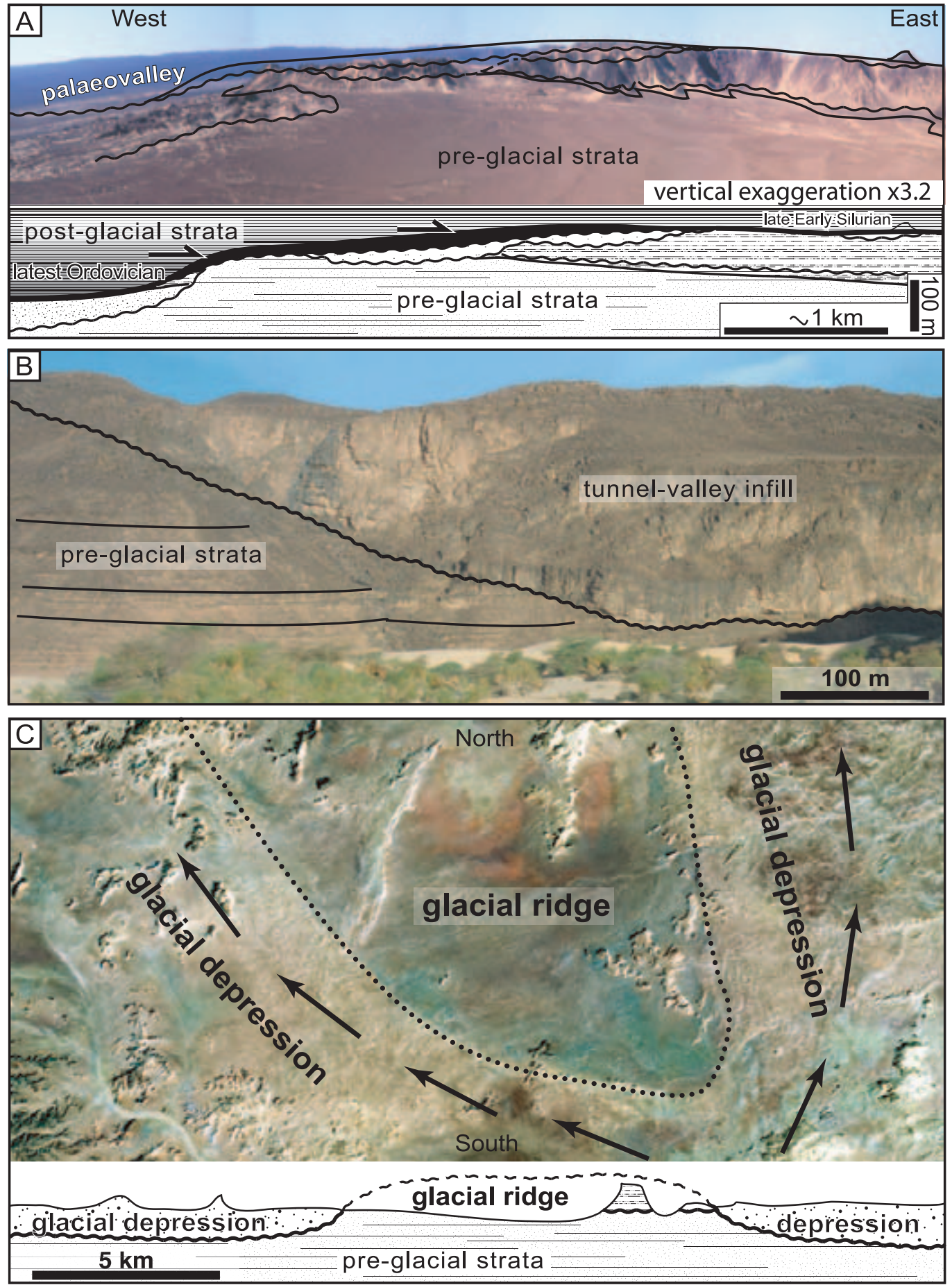

Fig. 3 Diversity in glacial erosion surfaces. (A) A wide palaeodepression within the Eastern Tassili n'Ajjer glacial trough (Ghat area, western Murzuq Basin, Libya) (view with vertical exaggeration, interpretation from field sections). Bounding surfaces of syn-glacial depositional units are gently dipping glacial erosion surfaces (wavy lines). The upper unit (in black) mainly represents a late to post glacial transgressive wedge, that reworked the latest glacial erosion surface (see also Fig. 5). The latest glacial palaeodepression was underfilled and post-glacial sediments progressively onlapped on the residual palaeotopography from the latest Ordovician to the Silurian (see also Fig. 9B). (B) An overfilled tunnel valley characterised by a narrow, steep-sided erosion surface (Adrar, Mauritania, modified from Ghienne \& Deynoux, 1998). (C) Landsat image showing a glacial ridge (inverted topography, present-day lower area) with two adjacent palaeovalley-like depressions into a glacial trough (Tihemboka Arch, western Murzuq Basin). 
(Fig. 3B). Conversely, basin-scale subglacial scours are inferred if the width is $>50 \mathrm{~km}$. In other circumstances, overdeepenings or the occurrence of erosional troughs that narrow in planform also suggest subglacial processes (Beuf et al., 1971). However, the most reliable subglacial erosion surfaces are those associated with subglacial lineations. Subglacial lineations (mega-scale glacial lineations, flow-parallel and attenuated drumlins) are characterised by parallel bedforms, $<100 \mathrm{~m}$ to $>10 \mathrm{~km}$ in length, 1-30 $\mathrm{m}$ in height, with high elongation ratios (>10) (Moreau et al., 2005) (Fig. 4 A, B \& C). Most of them are erosional features cored by older sediments. Only the sediments directly beneath the sediment-ice interface are affected by intense glaciotectonic deformation (Deynoux \& Ghienne, 2004, 2005).

The best outcrop-scale evidence for glacially cut erosion surfaces is preserved in the record of deformation structures formed beneath them as a combination of shear-induced and gravitational deformation structures within the sediment column. Glaciotectonic deformation includes all the deformation that can be linked with the subglacial shear zone. Structures or deposits resulting from processes at the ice-sediment interface (striae, grooves, lodgement till) are generally poorly preserved in the Late Ordovician glacial record (Deynoux \& Ghienne, 2005; Le Heron et al., 2005). Intraformational deformation structures are more readily preserved and are therefore most commonly observed. Soft-sediment intraformational striated surfaces (Fig. 4F) were formed at several metres in depth beneath the ice-sediment interface (Deynoux \& Ghienne, 2004; Le Heron et al., 2005). They are typically associated with intraformational grooves (Fig. 4D), drag and sheath folds (Fig. 4E), Riedel shears and water-escape structures. Intraformational striated surfaces are particularly well developed beneath mega-scale glacial lineations with which they are parallel. Deformation associated with glacial surfaces includes chaotic sandstone units ('grès bousculés' of Deynoux, 1980 and Deynoux \& Ghienne, 2004), large-scale loading structures such as domes, cylindrical folds and sediment diapirs (Le Heron et al., 2005), overturned fold and thrust-and-fold belts, 5-50 m high. However, the last may also occur in association with proglacial glaciotectonic processes, such as broadly arcuate belts, or with slide-generated structures.

\section{HIRNANTIAN GLACIES CYCLES AND PHASES}

It is established that the so-called Upper Ordovician syn-glacial strata in West and North Africa are, in fact, strictly Hirnantian in age (Destombes, 1968b; Destombes et al., 1985; Paris et al., 1995, 1998; Underwood et al., 1998; Sutcliffe et al., 2000). They are also time-equivalent with a significant isotopic excursion of global extent (Brenchley et al., 2003). The Hirnantian is generally considered to have lasted less than $1 \mathrm{Ma}$, but the new Ordovician timescale suggests that it could have been as long as 2 Ma (Webby et al., 2004) (Fig. 2). Within this time-slice, a number of glacial advances and subsequent retreats occurred (Ghienne, 2003). At present, the number, as well as the significance and extent, of each of these Hirnantian glacial events is not known, but is the subject of ongoing work. However, the comparison of the stratigraphic architecture of syn-glacial successions from distinct areas gives noteworthy temporal relationships.

\section{Areas closest to the ice centre}

Glacial erosion in the areas closest to the ice centre has resulted in reworking of pre-glacial sediments, and during later glacial phases, cannibalisation of the earlier glacial sequences. In these regions, geological mapping covering a minimum representative area of about $1000 \mathrm{~km}^{2}$ has revealed several, laterally juxtaposed glacial erosion surfaces (Fig. 5) that generate a complex stratigraphic architecture (Ghienne, 2003; Ghienne et al., 2003; Moreau, 2005).

Depositional sequences are bounded by subglacially-cut unconformities or correlative subaerial unconformities. These surfaces were formed regionally during major phases of glacial advance. Subaerial exposure commonly occurred beyond the ice front. Glacial depositional sequences, comprising a range of alluvial plain to shelf sediments (see below), were deposited on top of these surfaces during ice recession towards the south, and during ensuing interglacials. Four to five depositional sequences occur in Mauritania (Ghienne, 2003), Libya (Gargaf Uplift: Deynoux et al., 2000; Le Heron, 2004; Ghienne et al., 2003; western Murzuq Basin: Moreau, 2005; Moreau et al., 2005; Le Heron et al., in press, b) and Jordan (Turner et al., 2005). 


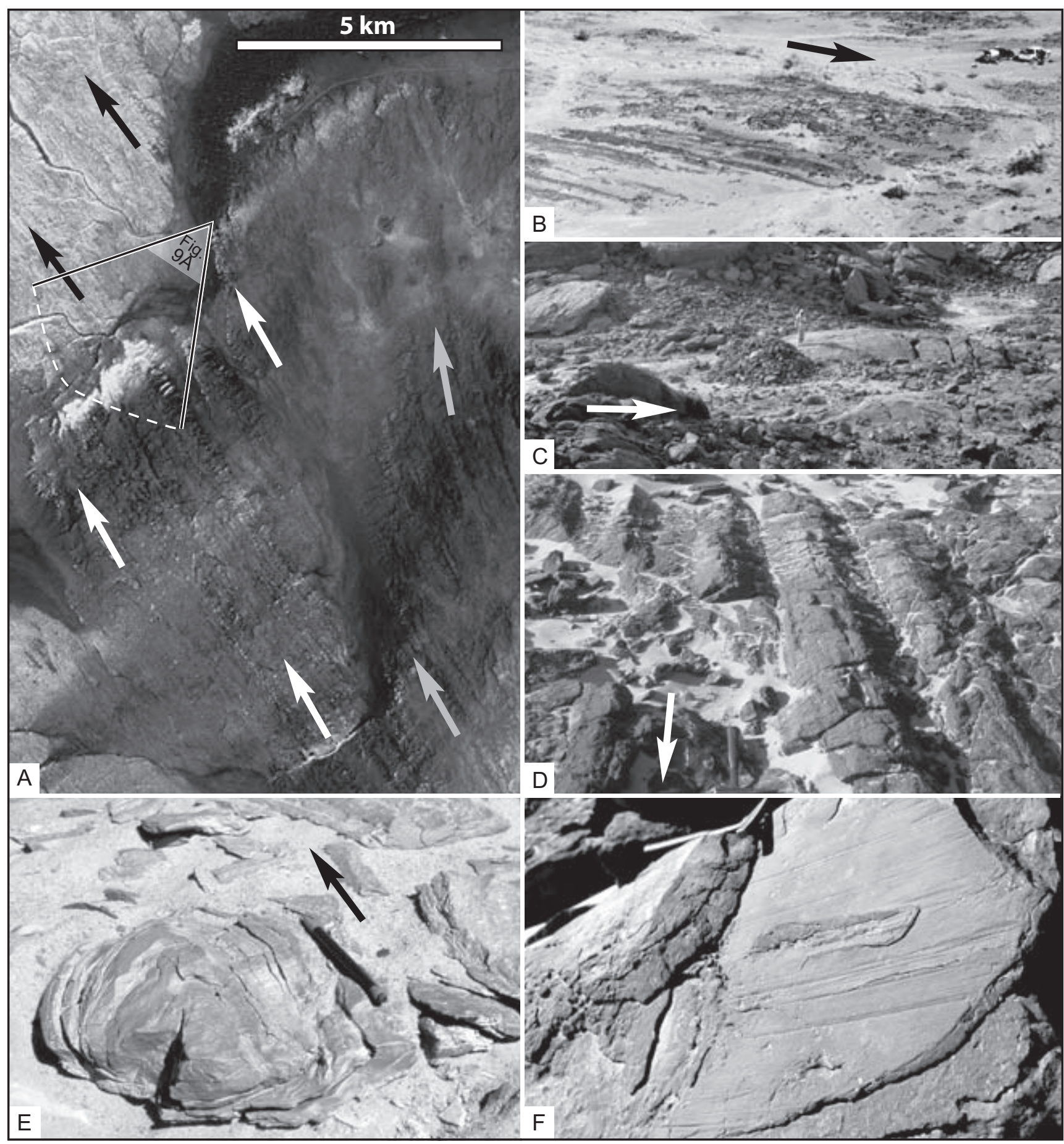

Fig. 4 Multi-scale glacial lineations associated with glacial erosion surfaces; all structures are in syn-glacial sands. Arrows show ice-flow orientation. (A) Landsat image showing three sets of ice-stream-generated mega-scale glacial lineations (Eastern Tassili n'Ajjer, Ghat area, western Murzuq Basin, Libya). (B) Glacial lineations (Tagant, Mauritania, cars for scale). (C) Asymmetrical glacial alignments shaped as a roche moutonnée (western Hodh, Mauritania, person for scale). (D) Grooves preserved within an intraformational subglacial shear zone (Ghat area, western Murzuq Basin, hammer for scale). (E) Sheath folds, the elongation of which is parallel to the shear orientation (Djado, Niger, pencil for scale). (F) Intraformational striae and ploughing structure in sandstones (Tihemboka Arch, western Murzuq Basin). 


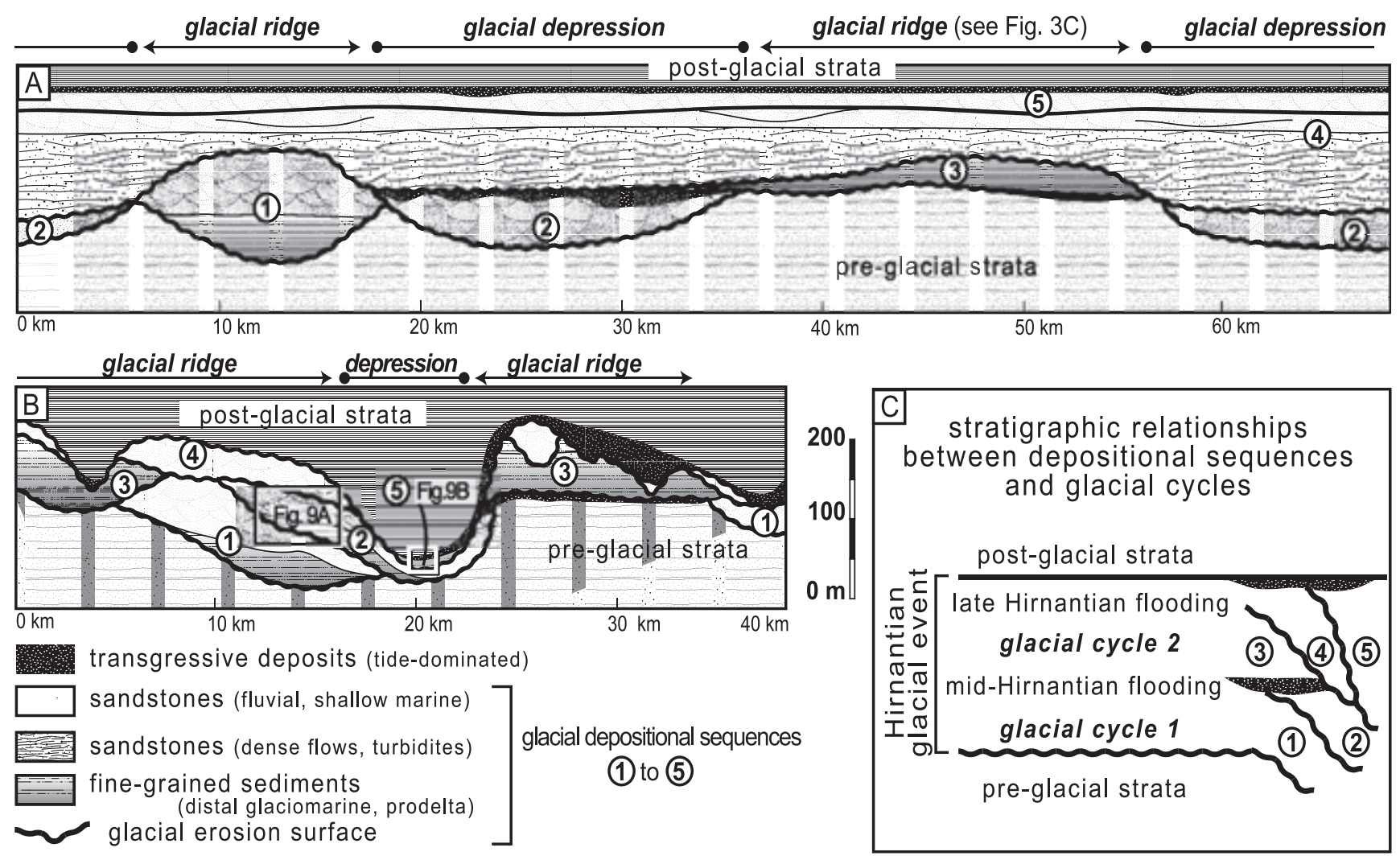

Fig. 5 Stratigraphic architecture of the syn-glacial strata in the western Murzuq Basin, Libya (profile location in Fig. 8A). Syn-glacial strata fill in palaeovalley-like depressions separated by glacial ridges. Indicated depressions and ridges were formed during the glacial maximum (fourth glacial phase). See text for more details about depositional facies. (A) Tihemboka Arch $\left(26^{\circ} 10^{\prime} \mathrm{N}\right)$. (B) Eastern Tassili n'Ajjer, Ghat area $\left(25^{\circ} \mathrm{N}\right)$. (C) Stratigraphic relationships and subdivision of the Hirnantian succession in two glacial cycles separated by the mid-Hirnantian deglaciation event, and five glacial phases of glacial advance and subsequent retreat.

In Mauritania and Libya, the most extensive ice sheet (e.g. phase 3 of Ghienne, 2003 in Mauritania; phase 4 of Moreau et al., 2005 in western Libya) occurred after a major transgressive event characterised by the deposition of a tide-dominated succession (Fig. 5). This transgression is interpreted as a major phase of deglaciation within the Hirnantian.

\section{Ice sheet margins}

In ice-marginal areas, the effects of glacial erosion are less pronounced. Bounding surfaces of successive glacial depositional sequences are frequently preserved within a single vertical section (e.g. Monod et al., 2003). A number of regressivetransgressive cycles are observed and interpreted in terms of glacioeustatically-driven rhythms (Leone et al., 1995). These areas also preserve evidence of three to five glacial events, as best exemplified by the glacial record of Morocco (e.g. Le Heron et al., in press, a) where the Hirnantian strata can be divided into two glacial successions separated by a major transgression (Fig. 6). This major transgression is interpreted to correlate with the deglaciation event associated with tidal deposits in areas closest to the ice centres. Furthermore, in Turkey, evidence for subglacial processes is found at only one stratigraphic interval (Monod et al., 2003) above well-developed transgressive deposits. These regionally correlatable features indicate that a key interglacial transgression was followed by the most widespread and significant phase of ice sheet advance across North Gondwana. 


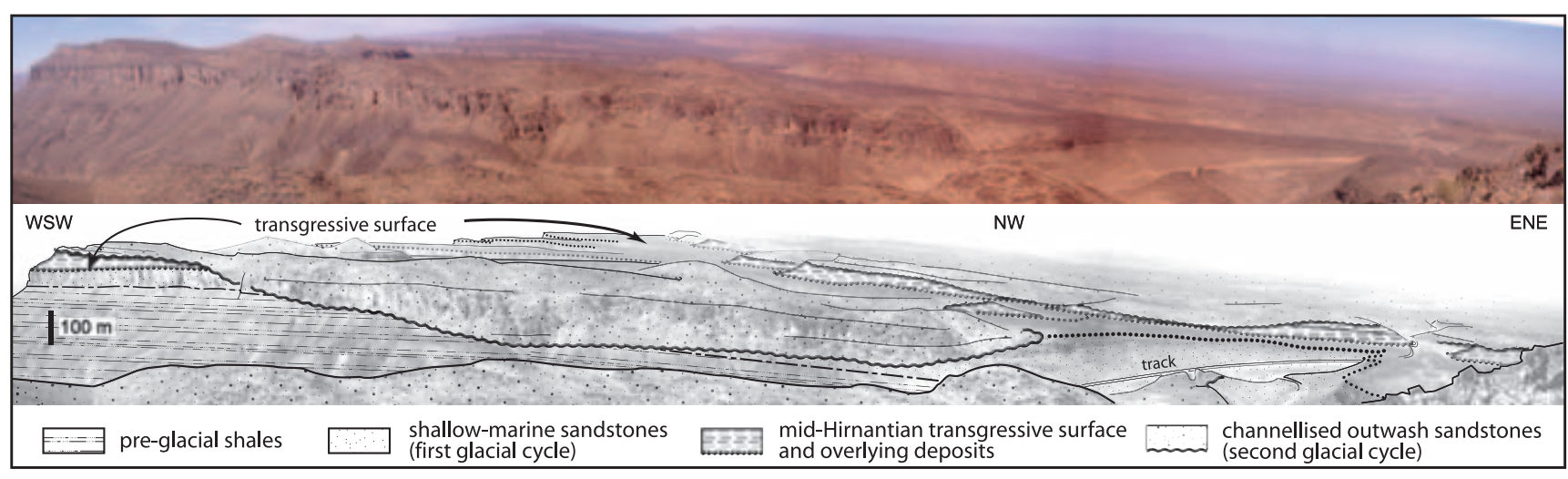

Fig. 6 The mid-Hirnantian deglaciation event in the Anti-Atlas (southern Morocco, northeast of Zagora). The glacially-related succession that mainly comprises shallow-marine and channellised outwash sandstones in contrast with pre-glacial shale-dominated sediments, is divided into two sedimentary wedges, separated by a major transgressive surface related to the mid-Hirnantian event. The panoramic view is c. $4 \mathrm{~km}$ in width in the foreground.

\section{The Hirnantian glacial event: a multiphase glaciation}

As glacial depositional sequences record major ice advances and retreats, they provide excellent potential for regional allostratigraphic correlation. The present understanding is that successive Hirnantian glacial events occurred within a single graptolite or chitinozoa biozone (extraordinarius and elongata Biozones respectively) (Paris et al., 1995). Because no biostratigraphic subdivision is currently available, the best chronostratigraphic marker is probably the mid-Hirnantian transgression detailed above. This event of great amplitude is recorded as far south as the Djado area (northern Niger, location in Fig. 1C). Here, fauna-rich marine shales, originally considered as pre-Hirnantian strata (Legrand, 1993), and now attributed to the extraordinarius Biozone (P. Storch, pers. comm., 2004) were deposited between two major glacial erosion surfaces (Denis et al., submitted). These data imply that the transgression advanced deep into North Africa at least within erosional troughs. This transgression is also recognised in non-glaciated area such as Sardinia (e.g. Storch \& Leone, 2003).

This transgressive interval, coeval with a major deglaciation event, subdivides the Hirnantian into two first-order glacial cycles (Sutcliffe et al., 2000) (Fig. 5C). Each cycle includes a limited number of glacial phases, the correlation of which throughout the North Gondwana is at present more controversial. At least two glacial phases are recognised within both the first (early Hirnantian) and the second (late Hirnantian) glacial cycles. Major ice recessions $(\sim 500 \mathrm{~km})$ occurred between two successive phases, to compare with the mid-Hirnantian deglaciation associated with ice-front retreats $>1000 \mathrm{~km}$, possibly much more (Moreau, 2005).

\section{Ice sheet size: the glacial maximum}

Accurate reconstruction of pre-Pleistocene ice sheets, and the demonstration of synchronous, continent-wide ice fronts, is not straightforward. The size of both Permo-Carboniferous (Eyles et al., 2003) and Neoproterozoic (Eyles \& Januszack, 2004) ice sheets has recently been challenged, because their size may have been affected by enhanced polar wander or rates of rift propagation. Even assuming a maximum duration for the Hirnantian of $2 \mathrm{Ma}$ (Webby et al., 2004), and although the opening of the Palaeotethys (rifting of the Hun superterrane of Stampfli \& Borel, 2002) occurred in Late Ordovician time, we argue here that these processes have not had a substantial impact on Hirnantian ice-sheet reconstructions. Synchronous growth of ice sheets, at least during the most protracted phase of glaciation, was likely from Mauritania to Turkey. This stands in contrast to Permo-Carboniferous centres of glaciation, which waxed and waned asynchronously over an interval of c. $55 \mathrm{Ma}$ (Eyles et al., 2003).

A reconstruction of the maximum size of the West Gondwana ice sheets, based on the occurrence of a regionally correlatable glacial erosion surface 


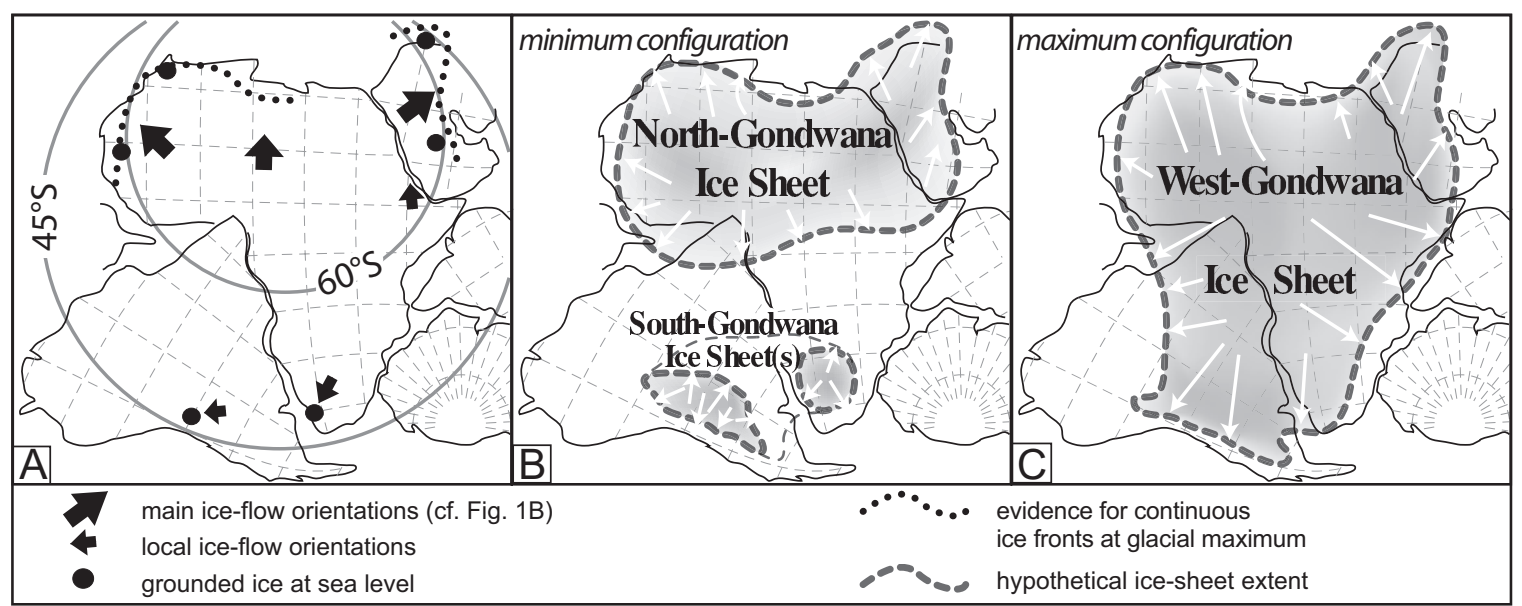

Fig. 7 The extent of the Late Ordovician glaciation. (A) Locations of identified subglacial deformation zones in the more distant areas from the ice centres. On the North Gondwana platform, these are from west to east: Tagant (western Mauritania), Rehamna (northern Morocco), Eastern Taurus (south-eastern Turkey) and Central Arabia. These four locations were glacierised at the Hirnantian glacial maximum, implying that grounded ice occurred at sea level close to the $60^{\circ} \mathrm{S}$ parallel. To include glacial successions from South America and South Africa (potentially of Hirnantian age) implies grounded ice occurring at sea level within the $45^{\circ} \mathrm{S}$ parallel. (B) The minimum-sized Hirnantian ice sheets, with a large North Gondwana Ice Sheet, and possibly penecontemporaneous subordinate ice centres in South America (linked with a pre-cordilleran setting) and South Africa, which may have coalesced together. (C) The maximum-sized Hirnantian West-Gondwana Ice Sheet, assuming fully coalescent synchronous glaciers.

following the major mid-Hirnantian interglacial, is presented in Fig. 7A. Ice-front migrations from place-to-place during the same glacial event (e.g. Boulton \& Clark, 1990; Boulton et al., 2001) means that ice fronts at the glacial maximum would have been best represented as an envelope rather than a continuous line. Late Ordovician ice fronts were continuous from Mauritania to western Libya. The existence of a continuous ice front between western Libya and Arabia is controversial, but likely at least during the most protracted phase of glaciation, which also affected southern Turkey (Monod et al., 2003). Although Upper Ordovician glacial successions are also known in South Africa (e.g. Hiller, 1992) and South America (Caputo, 1998; Diaz-Martinez et al., 2001), dating uncertainty still exists for the related glacial successions (e.g. Boucot et al., 2003 for the South African example).

At the Hirnantian glacial maximum, the sedimentary record supports the concept of a continuous ice sheet across North Africa that possibly extended into Arabia, with WNW-to-NE oriented ice flow directions (Figs. 1B \& 7A). A minimumsized ice sheet at the glacial maximum had to incorporate a roughly symmetrical ice-front line, depicting a North Gondwana Ice Sheet (the
Saharan Ice Sheet of Young et al., 2004), characterised by southward-flowing ice in sub-Saharan Africa (Fig. 7B). As ice flowed from south to north in Eritrea and Ethiopia (Kumpulainen, 2005; Fig. 7A), this minimum-sized ice sheet must have reached Central Africa. A maximum-sized Hirnantian ice sheet may, in addition, have overridden South America and South Africa where subglacial deformation zones have been also identified (Blignault, 1981; Martinez, 1998; Le Heron et al., 2004; Deynoux \& Ghienne, 2005) (Fig. 7C). The maximum-sized ice-sheet scenario envisages a huge West Gondwana Ice Sheet (Vaslet, 1990, Sutcliffe et al., 2000; Ghienne, 2003) centred above Central Africa where no Upper Ordovician sediments crop out.

\section{THE NORTH GONDWANA PLATFORM DURING THE HIRNANTIAN}

This section proposes the subdivision of the North Gondwana platform, from the ice centre to lower palaeolatitudes, into several palaeogeographic domains based on the number of glacial erosion surfaces preserved. A second palaeogeographical 
scheme is then presented, providing a subdivision of the ice sheet perpendicular to ice-flow lines based on the occurrence of ice-stream-generated glacial troughs.

\section{Palaeogeographic domains of the glaciated shelf}

The number of glacial erosion surfaces distributed regionally define five proximal-to-distal palaeogeographic domains in North Gondwana (Fig. 1C). The continental interior corresponds to a domain that was not deglaciated until the close of the Hirnantian. The dominance of subglacial and postglacial erosion in these areas means that the glacial record in this domain is limited and restricted to small-scale, fault-bounded intracontinental basins (Konaté et al., 2003). It is conceivable that the continental interior may have been glacierised both prior and after the Hirnantian glaciation.

The inner, middle and outer domains of the glaciated continental shelf were subject to multiple phases of ice-sheet growth and decay. On the inner glaciated shelf, typified by the Niger succession (Denis et al., submitted), two glacial erosion surfaces and associated overlying sequences are recorded, and, are separated by the mid-Hirnantian graptolitic shales (see above). This domain was deglaciated during the mid-Hirnantian, but remained glacierised during phases of ice-front retreat within each of the two first-order glacial cycles. Glacioisostacy should have played a significant role in developing thestratigraphic architecture. The middle glaciated shelf corresponds to the area subjected to from 2 to 5, possibly more, phases of subglacial erosion. In this zone, encompassing the well-known successions in Mauritania, Algeria and Libya, both glacio-eustatic and glacio-isostatic processes were operative, and the most complete record of multiple advance and retreat events of the Hirnantian ice sheets is preserved. The outer glaciated shelf, including northern Morocco and Turkey, was glacierised only during the most protracted advance phase of the Hirnantian glacial maximum (Figs. 1C \& 7A). Glacio-eustacy was probably more important than glacio-isostacy in these regions (e.g. Boulton, 1990). The shelf areas beyond the outer ice-sheet limit comprise a sedimentary record controlled solely by glacio-eustacy. In these areas, distal glaciomarine sediments are locally preserved (Fig. 1B; e.g. Sardinia, Brittany,
Bohemia: Robardet \& Doré, 1988 and references therein; western Taurus, Turkey: Monod et al., 2003; northernmost Morocco: Le Heron et al., in press).

\section{Ice sheet configuration: the case study of Algeria}

Legrand (1974, 1985) published a map of Algeria showing well-defined, 50-200 km wide, so-called sediment 'thicks' of 'upper Caradoc-Ashgill-lower Silurian' strata, separated by 150 to $300 \mathrm{~km}$ wide sediment 'thins'. This map is reproduced in Fig. 8A including data collected by the authors from Morocco (Anti-Atlas, Tamlelt area), Ougarta (NW Algeria) and Tassili n'Ajjer (western Murzuq Basin, Libya). It excludes smaller-scale variations, such as steep contour gradients over $<10 \mathrm{~km}$ that could be attributed to tunnel valley incisions or fluvial incised valleys. Recent biostratigraphic work confirms that the strata outlined by Legrand (1985) are well constrained to Hirnantian syn-glacial strata (Paris et al., 1995; Oulebsir \& Paris, 1995; Vecoli \& Le Hérissé, 2004).

It seems likely that areas with thick Hirnantian successions outline depositional lows and areas typified by thin successions designate palaeo-highs. North of the Hoggar, the data reviewed above are interpreted as a series of Late Ordovician glacially formed erosional troughs separated by plateaux or 'interfluves'. Four glacial troughs are identified across the Algerian middle glaciated shelf, from Ahnet to Tassili n'Ajjer, where the glaciogenic sediments reach $>300 \mathrm{~m}$ in thickness. It is stressed that the isopach maps may mask the amalgamation of multiple glacial cycles in the stratigraphic record. In the interfluves, with the exception of deep but narrow palaeovalleys, the contact between pre-glacial and syn-glacial strata is stratigraphically higher.

The glacial troughs are very difficult to identify in the field as they are comparable in scale to tectonic structures (e.g. zones of preferential subsidence or post-depositional lithospheric bending). However, the easternmost glacial trough on Fig. 7A is the northward extension of a glacial trough already described in western Libya (Moreau et al., 2005). This well-defined trough is $>200 \mathrm{~km}$ in length and $>80 \mathrm{~km}$ in width, and the depth of glacial erosion is up to $300 \mathrm{~m}$, despite residual relief forms occurring on the upper surface of pre-glacial strata (Fig. 5). This trough contains several glacial surfaces 

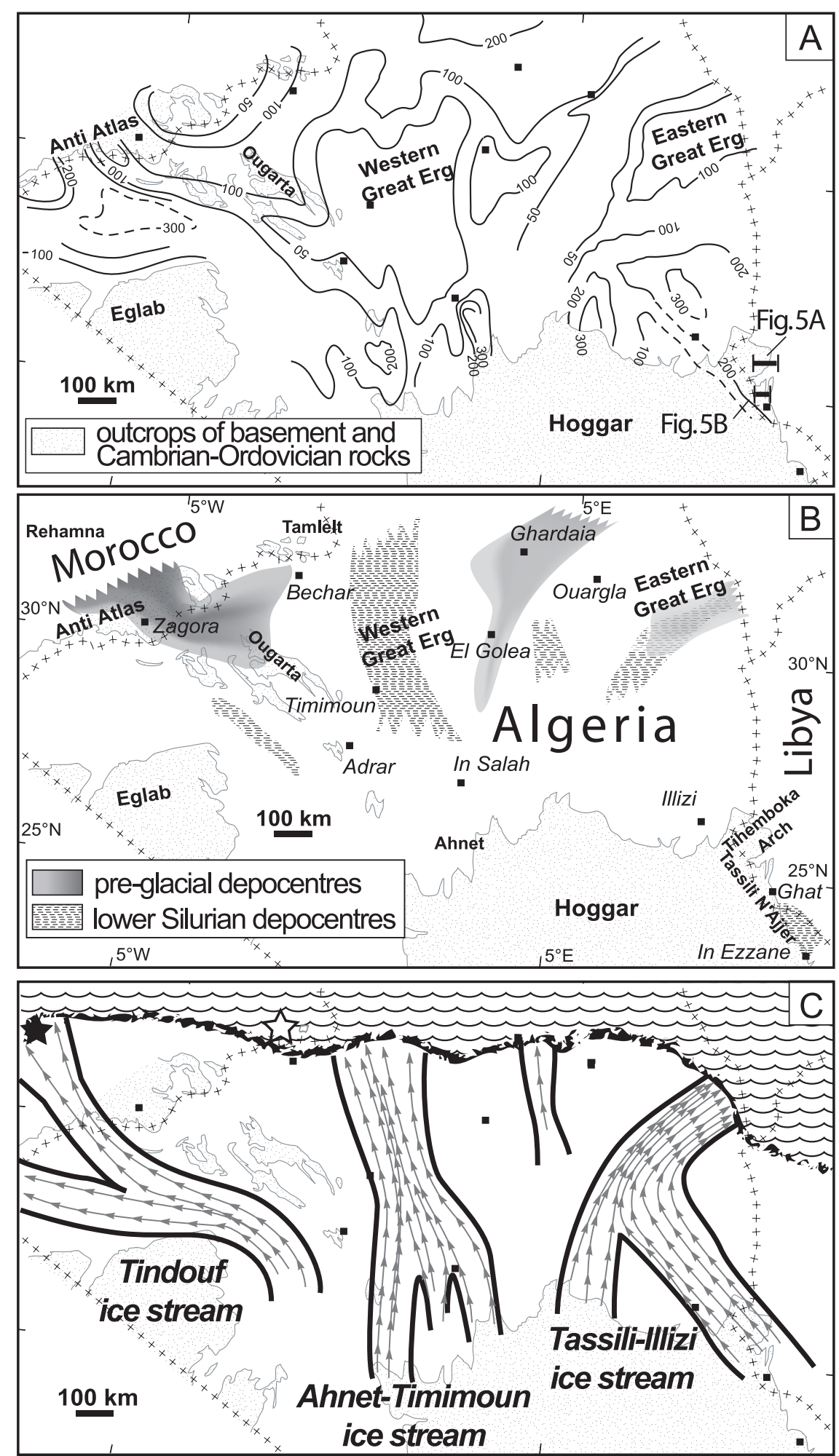

Fig. 8 Glacial troughs and ice streams in Algeria. (A) Isopach map corresponding to the syn-glacial Hirnantian strata (modified from Legrand, 1974). Erosional troughs are identified at the northern edge of the Hoggar Massif. (B) Pre-Hirnantian preferential depocentres (from Legrand, 1974 and Destombes et al., 1985) and earliest to Early Silurian depocentres corresponding to depositional lows (from Klitsczh, 1981; Legrand, 1985; Lüning et al., 2000). (C) Potential locations of major ice streams in Algeria as inferred from the locations of glacial erosional troughs and ice-flow orientations (cf. Fig. 1B). The black star is the northernmost glacierised area (Le Heron et al., in press, a); the white star indicates an area that was not glaciated (Tamlelt area, southeastern Morocco, unpublished data). Ice-stream fronts correspond to the Hirnantian glacial maximum. They are tentatively figured as shallow-marine ice fronts with no ice shelves. 
characterised by mega-scale glacial lineations (Fig. 4A) (Clark, 1993; Stokes \& Clark, 2001). These lineations have elongation ratios ranging from 5 to $>20$ and are 1-30 $\mathrm{m}$ in height. The lineations make up a large-scale undulating morphology on the glacial erosion surface, which is superimposed on wide elongated ridges separated by straight valleylike depressions (Figs. 3C \& 5). The morphology, comparable to the landforms produced by former Antarctic (e.g. Canals et al., 2000; Anderson et al., 2002; Evans et al., 2004) or Scandinavian (Ottesen et al., 2005) ice streams, defines a Late Ordovician ice-stream pathway (Moreau et al., 2005). As a working hypothesis, the other glacial troughs of Algeria are interpreted as palaeo ice-stream pathways.

North of the glacial troughs, the general thinning of the sediment wedge is interpreted either as a decrease in the depth of erosion, or a decrease of sediment thickness in glacial troughs that are gradually underfilled. The latter scheme makes sense with the occurrence of elongate areas that Legrand $(1985,2003)$ and Lüning et al. (2000) have mapped, where lower Silurian organic-rich shales preferentially occur (Fig. 7B). These elongate areas are interpreted as depositional lows within which postglacial lower Silurian deposits may have accumulated, in contrast to highs that were not covered by sediments until middle Silurian time. Those depositional lows are interpreted as reflecting glacial troughs that remained underfilled after the ice-sheet retreat.

Connecting the overfilled glacial troughs of the Hoggar Massif (Fig. 8A) with underfilled depressions containing lower Silurian deposits to the north (Fig. 8B), a network of ice streams is reconstructed at regional scale (Fig. 8C). Hence, the Late Ordovician ice sheet over Algeria and western Libya was drained by a number of north-flowing ice streams separated by more stagnant ice in inter-stream areas. The shelfbreak extended a long distance from the ice fronts (Fig. 8C) and the existence of a shallow shelf ( $<200 \mathrm{~m}$ deep) may have restricted the formation of extensive frontal ice shelves.

More subtle depocentres are found northward in the Algerian outer glaciated shelf. However, they coincide spatially with pre-glacial depocentres (Fig. 8B) and are therefore not interpreted as erosional features. They cannot be considered as proxies for distal ice-stream pathways.

\section{STRATIGRAPHIC ARCHITECTURES IN THE LATE ORDOVICIAN GLACIAL RECORD}

Distinctive stratigraphic architectures faithfully reflect the position of each area on the shelf. For instance, low accommodation space and repeated 'cannibalisation' characterised the middle glaciated shelf, while restricted glacial erosion and greater accommodation space prevail on the outer glaciated shelf. This palaeogeographic subdivision of the glaciated shelf, parallel to ice flow, is coupled with a flow-transverse subdivision of the ice sheet into ice-stream troughs and inter-stream areas. That means a great deal of lateral variability should exist in the Late Ordovician glacial record. In the following section, the stratigraphic architectures of ice-stream pathways and inter-stream areas are compared for the middle and outer glaciated shelf.

\section{Ice-stream-related depositional systems}

The middle glaciated shelf: western Libya

In the Murzuq Basin (Libya), the depositional succession of the Hirnantian glacial record has been studied extensively (McDougall \& Martin, 2000; Deynoux et al., 2000; Sutcliffe et al., 2000; Ghienne et al., 2003; Le Heron, 2004; Le Heron et al., 2004; El-ghali, 2005; Le Heron et al., 2005). Most of the interpretations are based on field studies conducted in the Gargaf area, in the northern Murzuq Basin. In the following, we developed to some extent the glacial record of the western Murzuq Basin (Eastern Tassili n'Ajjer and Tihemboka Arch, see location in Fig. 8B). It characterises the stratigraphic architecture in ice-stream pathways on the middle glaciated shelf.

Despite partial reworking during later glacial cycles, 4-5 glacial depositional sequences are recognised, each separated by subglacial unconformities (Deynoux \& Ghienne, 2004; Moreau et al., 2005). The erosion depth of an individual unconformity is up to $200 \mathrm{~m}$. The total thickness of the syn-glacial succession approaches $250-300 \mathrm{~m}$. These sequences record the progressive infilling of glacially cut palaeovalley-like depressions. The long axis of younger depressions deviates from older examples (e.g. Smart, 2000), resulting in a complex depositional architecture (Figs 4A \& 5) akin to Late Cenozoic alluvial terraces (e.g. Blum \& Törnqvist, 2000). 

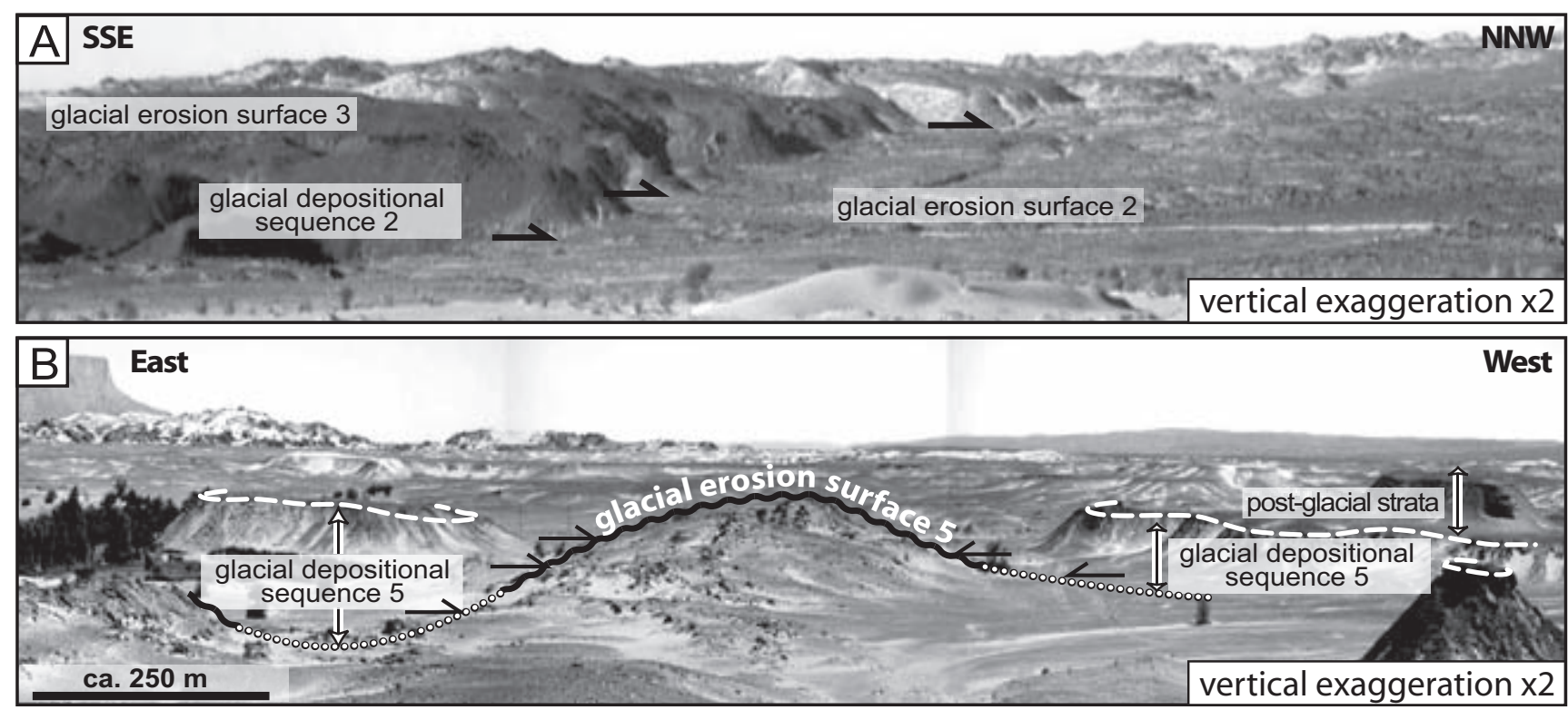

Fig. 9 Onlap relationships (black arrows) in the syn-glacial strata of the Eastern Tassili n'Ajjer (Ghat area, western Murzuq Basin). (A) A glacial depositional sequence onlaps on a glacial erosional surface with mega-scale glacial lineations (see location Fig. 4A). It is made up of fine-grained deposits at the base (distal glaciomarine, prodelta), truncated by fluvial sandstones at the top (depositional sequence 2 in Fig. 5B). (B) Glaciomarine and shelf deposits onlapping on a surface with mega-scale glacial lineations (depositional sequence 5 in Fig. 5B).

Depositional sequences 1-3. In the Eastern Tassili n'Ajjer (Ghat area), sequences 1-3 comprise coarsening upward successions, each $30-100 \mathrm{~m}$ thick bounded above and below by a glacial erosion surface (Figs. 5B \& 9A). Sequences 1 and 2 belong to the first glacial cycle, and sequence 3 to the second glacial cycle (Fig. 5C). The lowermost 20$75 \mathrm{~m}$ of each sequence comprises crudely laminated micaceous sandstones and shales with occasional lonestone-bearing diamictite horizons. These are interpreted as distal glaciomarine (plume) deposits or prodelta sediments. The middle section, 5-20 m thick, rests with a sharp or rapid transitional contact with the underlying section, and comprises well sorted medium-grained to poorly sorted coarsegrained sandstones. These deposits contain current and wave ripples, trough or tabular cross-laminae and plane beds with parting lineations. They are interpreted as shallow-marine to distal alluvial plain deposits. The upper part of each sequence includes sharp-based, coarse- to very coarse-grained sandstones bearing numerous internal erosional surfaces. Cross-laminated sandstones grade laterally into fine- to medium grained sandstones bearing horizontal to low-angle lamination with parting lineations and climbing ripple crosslamination. These are interpreted as a series of amalgamated fluvial channels and associated overbank sediments, deposited on a flood-dominated aggrading braid-plain.

Each depositional sequence is considered to record (i) rapid retreat of a marine-terminating ice front, followed by (ii) flooding of the glacial erosion surface, then (iii) progradation of a fluvial-delta-shelf system. A braid-plain separated the retreating, land-terminating ice margin from the shoreline. An abrupt facies change occurs within the prograding succession, either pointed out by sharp-based shallow marine deposits or by erosionally based fluvial deposits. In each of these sequences, a sea-level fall or a fluvial incision may be attributable to the effect of glacio-isostacy. Fluvial aggradation is concomitant with renewed progradation.

Depositional sequence 4. This sequence is associated with the Hirnantian glacial maximum that occurred during the second glacial cycle (see above) (Fig. 5C). In the Tihemboka Arch, a thick sandstone wedge has been deposited on the glacial erosion surface (Fig. 5A). It is overlain by a sandstone 
sheet, which can be followed to the south into the Eastern Tassili n'Ajjer, resting here directly on the basal glacial erosion surface (Fig. 5A \& B).

The sandstone wedge, $75-150 \mathrm{~m}$ thick, displays a coarsening and thickening-upward succession. The sandstones pass upwards from fine-grained massive sandy deposits, through a poorly stratified, medium-grained section characterised by sharpbased, horizontally laminated, graded, and dewatered sandstones, to low-angle or horizontally laminated deposits at the top. This succession is overlain by a channel-overbank system comprising cross-bedded medium- to coarse-grained sandstones. Channel fill structures, $10-40 \mathrm{~m}$ in thick- ness, $0.2-1 \mathrm{~km}$ in width, have transitional contact with overbank facies and any levee structures have been identified. These sandstones contain abundant subcritical climbing megaripples in 2$20 \mathrm{~m}$ thick beds (Fig. 10A \& B), associated with deep-sided cut-and-fill structures and undulating bedforms that show a steep climbing $\left(40^{\circ}\right)$ to aggradational $\left(90^{\circ}\right)$ superposition (Fig. 10C). Large glaciotectonic structures in the form of thrusted fold belts (20-40 $\mathrm{m}$ in height) are also preserved within these strata.

The coarsening sandstone wedge described above is capped by a medium-grained sandstone sheet, extending from the Eastern Tassili n'Ajjer
Fig. 10 Flood (possibly outburst)dominated facies in an ice-streamrelated outwash fan (glacial depositional sequence 4, Tihemboka Arch, western Murzuq Basin). (A) 2D climbing dunes composed of medium- to coarse-grained sandstones forming a $10 \mathrm{~m}$-thick depositional package. (B) Close up view of facies illustrated in (A). (C) Nearly symmetrical, vertically climbing, large-scale bedforms interpreted as oversupplied climbing dunes or alternatively antidunes (encircled hammer for scale).

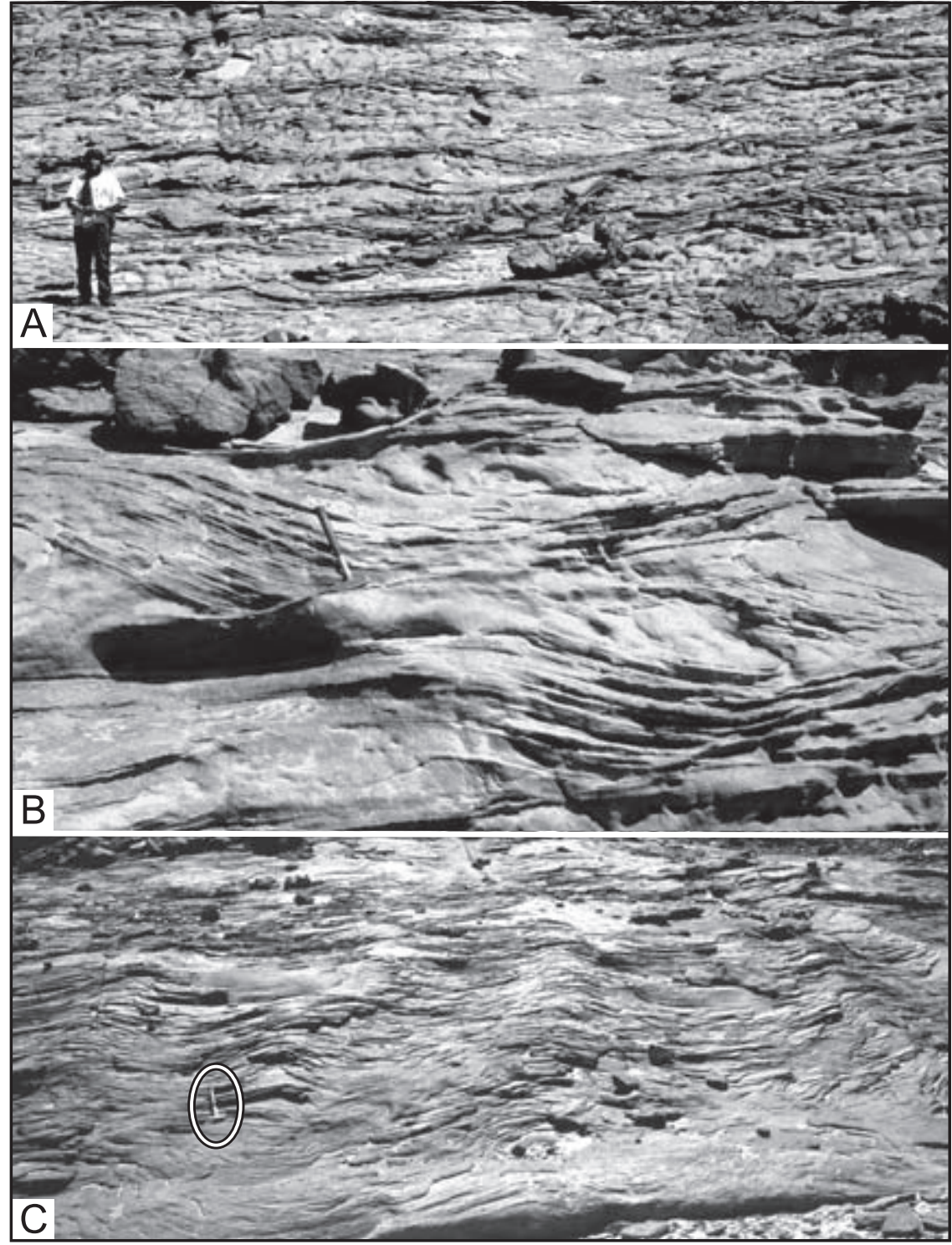


to the Tihemboka Arch. Its internal architecture is characterised by channel-fill structures and epsilon cross-stratification. The size of these structures increases towards the north. Horizontal lamination, climbing ripples and megaripples are ubiquitous.

Within the sandstone wedge, the climbing megaripples suggest deposition from highly concentrated sediment-laden streamflows with high rates of sediment fall-out. Such highly concentrated flows are most probably achievable by long-lived, turbulent glacial outburst floods (Russell \& Arnott, 2003; Russell et al., 2003). The origin of undulating climbing to aggradational bedforms (Fig. 10C) is enigmatic, and could reflect over-supplied climbing megaripples or alternatively antidunes. This last interpretation has been proposed for correlative deposits near Djanet, Algeria (Hirst et al., 2002). Distal counterparts of this flood-dominated environment comprise poorly stratified to massive, largely dewatered sandstones deposited in environments dominated by high-density sandy turbidites. The overall sandstone wedge is interpreted as an ice-contact, flood-dominated outwash fan. The channel structures form the distributary system, which was directly linked with the subglacial drainage system. It is uncertain whether the sandstone wedge was deposited on a large submarine outwash related to a marine ice front or as part of a fan delta system related to an ice front terminating on land. In either case, its scale exceeds comparable depositional systems in the literature (Powell, 1990; Lønne, 1995; Lønne et al., 2001) by one to two orders of magnitude. The size and thickness of the sand wedge suggests that the ice-sheet retreat occurred in the study area much more slowly than for sequences $1-3$. This suggests that deposition occurred during a phase of stabilisation of the ice sheet. The overlying sandstone sheet was deposited by a regional-wide sinuous to meandering, sanddominated fluvial system when ice-front position retreated further to the south and a delta most probably developed to the north.

Depositional sequence 5 . This sequence is restricted to the Ghat area (Eastern Tassili n'Ajjer) and is considered as compelling evidence for a locally developed, fifth phase of ice-sheet advance. To the north of a boundary zone corresponding to the maximum ice advance, a sandstone wedge that is similar to but thinner than that of sequence 4 , contains a channel-fill network and associated overbank deposits. To the south of the boundary zone, a glacial erosion surface bears fan-shaped drumlins with associated subglacial channel fills, both of which cross-cut older glacial lineations (Moreau et al., 2005). A thin veneer (5-20 m) of distal glaciomarine deposits caps this surface in the axis of glacially cut depressions that remained essentially underfilled after the ice sheet retreated (Figs. 3A, 5B \& 9B).

This depositional sequence had preserved the spatial relationship between a subglacial drainage network to the north and the proglacial outwash system to the south. The thin glaciomarine deposits that blanket the glacial surface suggest a rapid ice-sheet withdrawal. Post glacial evolution in a very last phase of Ordovician sedimentation was characterised by tide-dominated reworking processes and the deposition of a transgressive wedge on the flanks of underfilled palaeovalleys (Figs 3A and $5 \mathrm{~B}$ ).

\section{The outer glaciated shelf: High Atlas and Meseta (Morocco)}

Glacial troughs have not been found at outcrop on the outer glaciated shelf. However, a large depocentre of marine sediments has been identified in northeastern Morocco (Tazzeka Massif, Khoukhi \& Hamoumi, 2001) beyond the maximum ice-front position on the non-glaciated shelf. Here, a relatively deep (200-400 m) marine fan was deposited at the continental margin (Le Heron et al., in press, a). This fan system is not an analogue to the troughmouth fans identified in front of Quaternary ice streams beyond the shelfbreak (Vorren \& Laberg, 1997), within which sedimentation is dominated by very thick, poorly evolved diamictite facies. However, focused and massive sand-dominated deposition is interpreted as the signature of a sediment delivery system fed by an ice stream.

To the south, on the outer glaciated shelf, the two major Hirnantian glacial cycles are recorded, with sediments related to the first (lower) glacial cycle being somewhat more ice-distal than those of the second (upper) glacial cycle. Only the latter is discussed below. Further details are given in Le Heron et al. (in press, a).

In the Rehamna inlier, a thin sandy diamictite interpreted as a till is observed in close association with subglacial features such as glaciofluvial 
Fig. 11 The glacial succession in the High Atlas (Morocco). The following events are illustrated: (i) glaciotectonic deformation involving glaciomarine outwash fan facies, deposits of the first glacial cycle and subordinate pre-glacial strata, (ii) incision of a subglacial channel and sandy diamictite infill, (iii) truncation by a glacial erosion surface comprising streamlined bedforms (not illustrated, see Le Heron et al., in press, a).

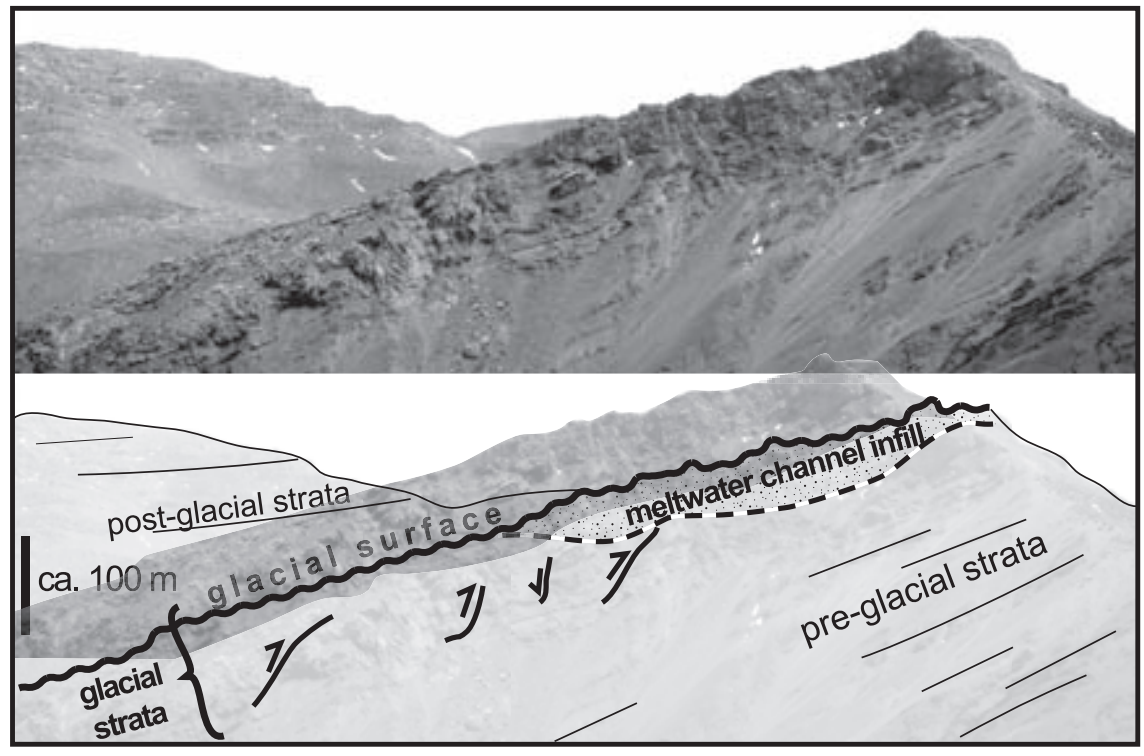

sandstones, sand intrusions and a striated surface. This till horizon rest above thin outwash facies and is overlain by well developed glaciomarine diamictite facies, up to $20 \mathrm{~m}$ thick. In the High Atlas, c. $100 \mathrm{~km}$ further to the south, the sedimentary succession of the second glacial cycle begins with thick outwash facies comprising sandstones interstratified with massive to poorly stratified, sandy, clast-poor diamictites (Ouanaimi, 1998). These sediments are deformed by glaciotectonic thrusts and gravitational loads, and are truncated by $20-40 \mathrm{~m}$ thick, 100-300 m wide channel structures (Fig. 10). The latter are filled with stratified coarse-grained sandstones, sandy diamictites and subordinate conglomerate lenses, including boulder-sized clasts of local origin. These deposits are capped by a glacial erosion surface with subglacial streamlined bedforms overlain by a thin $(<2 \mathrm{~m})$ diamictite.

The Rehamna succession, probably in close proximity to the maximum ice-front position, reflects more ice-marginal conditions than the High Atlas succession (Le Heron et al., in press, a). Glaciomarine diamictites overlying the glacial surface in the Rehamna were probably deposited during an earlier phase of ice-front recession. This stage has immediately preceded an ice-sheet collapse that prevented further glacial sedimentation over the area, as suggested by the thin 'post-glacial' glaciomarine sediment blanket above the underlying glacial erosion surface in the High Atlas.
Combining observations from the three study areas (Tazzeka, Rehamna and High Atlas), the Moroccan succession related to the Hirnantian glacial maximum records: (i) deposition in a submarine, ice-contact outwash fan dominated by mass-flow diamictites and sandy turbidites, (ii) glaciotectonic deformation and incision by channels suggesting subglacial, focused, sediment input points, (iii) subglacial conditions characterised by fast-flowing ice indicated by streamlined bedforms on the outer glaciated shelf, whereas an ice-stream-related 'deep' marine fan developed on the non-glaciated shelf, and (iv) a rapid ice-sheet withdrawal. A depositional succession related to a glacial advance on a shallow-marine shelf, followed by the development of an ice stream and a subsequent ice-stream collapse is then apparent.

\section{Depositional systems in inter-stream areas}

The middle glaciated platform: Mauritania

Syn-glacial strata in eastern and western Mauritania (Hodh and Adrar, Fig. 1) are organised into four laterally juxtaposed and vertically superimposed depositional units (Ghienne, 2003). As in Libya, each depositional sequence rests on a glacial erosion surface and records essentially an ice-sheet recession with the influence of glacial processes rapidly disappearing up-section. Key differences with the 
record in western Libya include (i) a markedly thinner succession (c. 40-100 m), thickening only within palaeovalleys or subglacial depressions, (ii) widespread palaeorelief forms on the upper surface of pre-glacial strata, (iii) better developed fluvio-glacial, fluvial and delta facies, and (iv) poorly developed offshore marine facies.

In the Hodh area, syn-glacial strata of the first Hirnantian glacial cycle record the recession of a land-terminating ice margin characterised by episodic, high-frequency retreats and re-advances of the ice front, resulting in a complex depositional architecture (Deynoux, 1985; Ghienne, 2003). This architecture includes aggrading outwash sediments deposited near a stagnating ice front that is partly glaciotectonised by minor re-advances. Both tills and some glaciofluvial material were reworked by gravity processes and re-deposited in subglacially overdeepened zones (Ghienne, 1998). The final phase of ice retreat was accompanied by the incision and subsequent infilling of large subglacial or proglacial meltwater channels (Ghienne, 2003).

During the second glacial cycle, a rather thin $(<50 \mathrm{~m})$ succession was deposited, with the exception of tunnel-valley infills (Ghienne \& Deynoux, 1998; Fig. 3B). The last depositional sequence lacks any glacial features in western Mauritania where erosion prevailed in shallow-marine environments. In the east, in the Hodh area, the sequence comprises a fining-up glaciomarine succession, characterised by thin $(<10 \mathrm{~m})$ submarine outwash-fan deposits at its base, truncated by nearshore sediments. This sequence indicates a significant relative sea-level fall ascribed to a late post-glacial isostatic rebound (Ghienne, 1998, 2003). It occurred, nevertheless, before the end of the Hirnantian (Paris et al., 1998; Underwood et al., 1998).

The outer glaciated shelf: Turkey (Taurus Mountains)

This area is characterised by laterally extensive (up to $100 \mathrm{~km}$ ), superimposed depositional units (Monod et al., 2003). Relatively clast-rich sandy diamictites, representing mass-flow or low- to highdensity sandy turbidites, characterise glaciomarine outwash environments in front of a marineterminating ice margin. The absence of large-scale channel structures suggest a limited availability of meltwater and line, rather than point, sources (e.g. grounding-line fans). Non-glacial shelf processes, e.g. storm deposits, are also present. A rather condensed shelf sedimentation regime not influenced by glacial processes, occurred during interglacial periods.

The glacial maximum is characterised by the deposition of a thin $(<0.2 \mathrm{~m})$ till horizon overlying a striated pavement. Upwards, a progressively fining-up, lonestone bearing glaciomarine succession records a gradual ice-front retreat. Therefore, in contrast to Moroccan successions, no evidence for a rapid ice-sheet withdrawal is identified in Turkey.

\section{PLATFORM-SCALE FACIES MODEL}

Only rarely have sequence stratigraphic methodologies have been applied successfully in glacial settings (e.g. Proust \& Deynoux, 1993; Brookfield \& Martini, 1999; El-ghali, 2005). Large-scale facies models for glacial sedimentary systems are thus still needed. When developed, they will form the basis of a more robust sequence stratigraphic approach to ancient glacial successions.

The database presented herein is regionally comprehensive (Fig. 1A) and should facilitate correlation of Late Ordovician depositional sequences across the North Gondwana platform. This correlation is complicated both by the number of palaeogeographic domains (e.g. inner, middle, outer glaciated shelves) and whether each study area lies within an ice-stream pathway or an inter-stream area. Based on the glacier dynamics inferred for each study area, a facies model illustrating the stratigraphic architecture of a glacial sequence is now proposed for two parallel S-N profiles (Fig. 12). The first set of diagrams on the left illustrates the stratigraphy within an ice-stream pathway, whereas the set on the right depicts an adjacent co-evally evolving inter-stream area. The model captures four phases in the temporal evolution of a glacial sequence, namely the glacial advance, the glacial maximum, the ice-margin recession and the interglacial minimum. The two points of maximum ice advance and ice retreat, as well as the marine limit, are not fixed palaeogeographically. They are located at different positions across the platform according to the amplitude of both the maximum and minimum ice extent associated with each glacial phase. 

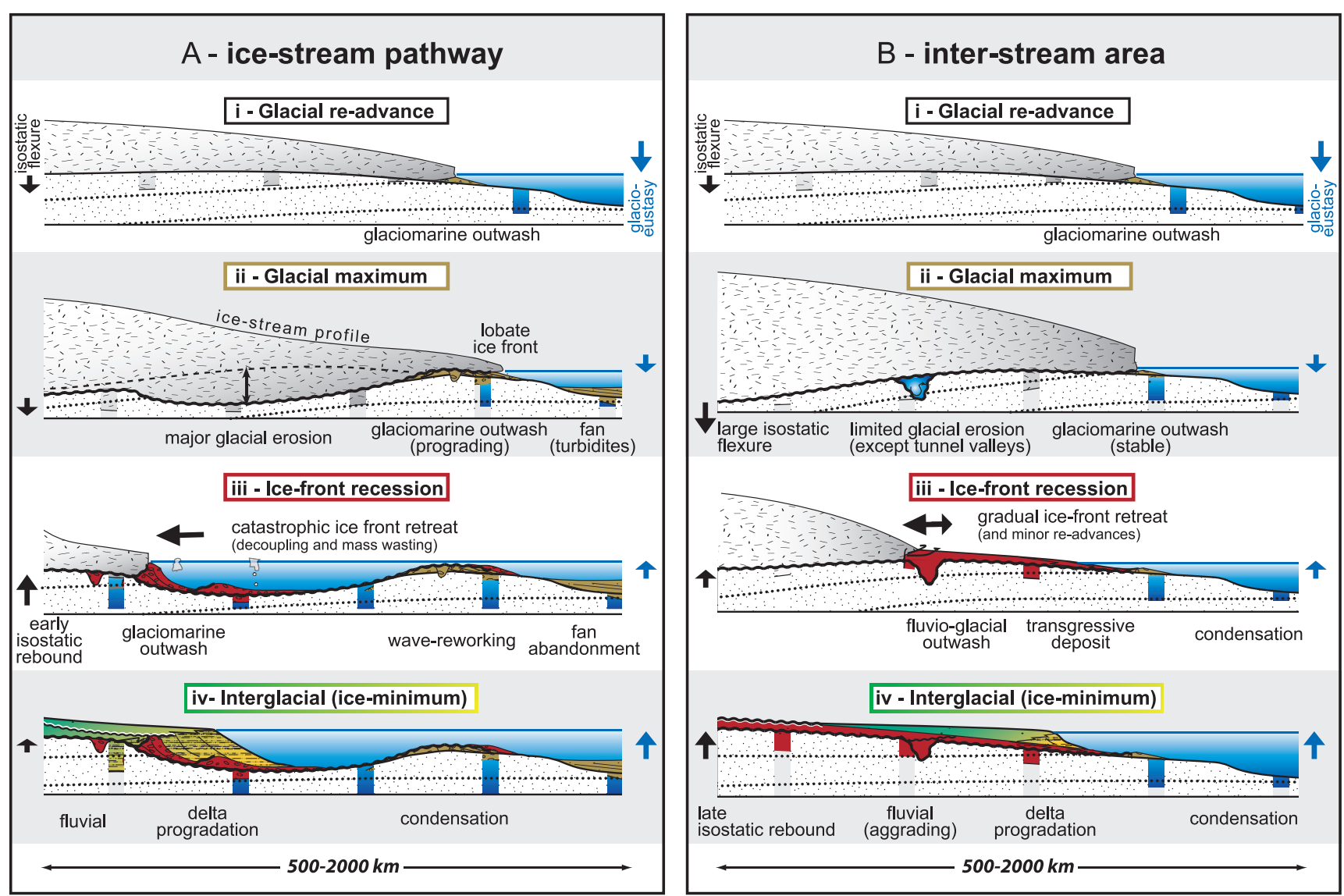

Fig. 12 An idealised glacial depositional sequence corresponding to a single glacial phase (glacial advance and subsequent retreat) in (A) ice-stream-related depositional environments (left, mainly based on the Libyan case study) and (B) inter-stream areas (right, mainly based on the Mauritanian case study, Ghienne et al., 2003). (i) Glacial re-advance. (ii) Glacial maximum and initial retreat. (iii) Ice-front recession. (iv) interglacial (ice-minimum). The stratigraphic superposition of several glacial sequences (2-5), and the potential lateral migration of ice streams result in an intricate glacial record (e.g. Fig. 5). Post-glacial transgressive deposits are not figured. Vertical exaggeration: $\sim 1000$.

\section{Glacial advance}

This stage is generally poorly recorded on the glaciated platform where regressive successions are poorly developed possibly due to a rapid sealevel fall. Immediately prior to the ice maximum, glaciomarine outwash sediments are deposited in some areas such as northern Morocco. This infilling of accommodation space probably supported the ice sheet as it advanced northward on the shallow-marine platform, and was affected by concomitant fall in sea-level (e.g. Dahlgren et al., 2002). It is not possible to ascertain whether ice streams had developed at this stage.

\section{Glacial maximum and initial glacial retreat}

While glaciomarine deposition occurred at the ice margin, subglacial erosion surfaces developed to the south. They are characterised by foredeepened depressions, glaciotectonic thrusts and folds, megascale glacial lineations and meltwater channels.

Focused sediment input-points located in front of ice-stream systems, may have been locally connected to some deeper turbiditic fans beyond a shelf edge inherited from the pre-glacial shelf architecture (e.g. in northern Morocco). This shelf edge may have controlled the maximum ice-stream advance (Le Heron et al., in press, a), which does 
not appear to have reached the shelf-break, unlike ice sheets in Antarctica or Scandinavia during the Pleistocene Late Glacial Maximum (e.g. Ottesen et al., 2005).

In contrast, linear and distributed sediment-input points built small-scale, diamictite-dominated outwash systems in front of inter-stream areas (e.g. in Turkey). Initial glacial retreat was generally associated with the deposition of relatively thick glaciomarine succession above a thin till. It is at this stage that large tunnel valleys began forming up-glacier in the inter-stream areas (e.g. Le Heron et al., 2004).

\section{Ice-front recession}

As ice stream retreat, only a thin sediment cover remains, comprising fine-grained distal glaciomarine deposits that rest directly on top of each glacial erosion surface as in the eastern Tassili n'Ajjer. The preservation of fine-grained sediment above glacial erosion surfaces implies the sudden withdrawal of the ice sheet from the outer glaciated shelf. These processes strongly suggest decoupling at the ice/bed interface, mass-wasting, rapid retreat of marine-terminating ice fronts to a new set of pinning-points, and flooding of the deglaciated area (Eyles \& McCabe, 1989; Anderson \& Thomas, 1991). This suite of processes is in agreement with the interpretation of a glacial trough as a former ice-stream pathway, characterised by foredeepened topography where intense calving may have occurred. After initial rapid retreat, a more stable and slow retreat of ice fronts produced a renewed and voluminous ice-contact, flood-dominated, outwash system such as a submarine fan or fan delta (sequence 4, Tihemboka Arch). The latter system then evolves into a delta system once a flooddominated fluvial plain becomes established in front of the land-terminating ice margin.

In inter-stream areas, the sediments from the icesheet recession stage comprise the tunnel-valley basal infill (Ghienne \& Deynoux, 1998; Le Heron et al., 2004). Glacial recession was more gradual as no sudden glacial withdrawal is observed (Turkey). With slow continuous retreat, a land-terminating ice margin deposited braided outwash sediments grading seaward into transgressive, shallow-marine deposits such as in Mauritania. During this time, a land-terminating ice margin may have persisted locally in inter-stream areas in a position to the north of some marine ice fronts that were established to the south in the axis of adjacent glacial troughs. Such a complex configuration may explain some peculiar fluvio-glacial drainage patterns. A source in a higher inter-stream area and a depocentre located within an adjacent glacial trough may be inferred when delta systems show evidence of progradation perpendicular to the regional palaeoslope

\section{Interglacial (ice-minimum)}

In both ice-stream and inter-stream areas, interglacial conditions resulted in high sea levels and the progradation of fluvial-delta-shelf systems as in western Libya and Mauritania. Fluvial aggradation occurs, locally temporarily interrupted by glacio-isostatic rebound. This aggradationalprogradational pattern infilled any remaining accommodation space in glacially cut glacial troughs and tunnel valleys. In the proximal (southern) parts of the shelf, these sediments may actually form the bulk of syn-glacial strata preserved within each glacial depositional sequence. In northern parts of the platform, more restricted or condensed sedimentation occurs, although this may also have been fed by local highlands providing an additional sediment source (Le Heron et al., in press, a).

\section{CONCLUSIONS}

The model given above should be regarded as a first attempt to merge numerous observations and interpretations in various parts of Northern Gondwana. The architecture of Late Ordovician glacial depositional sequences is mainly controlled by their location within or outside an ice-streamgenerated trough. Ice-stream-dominated systems are characterised by up to $300 \mathrm{~m}$ deep incisions, a greater sediment supply typified by flooddominated outwash-fan sedimentation, and a sedimentary record indicating rapid ice-sheet collapse. In inter-stream areas, shallower erosion surfaces are observed and sediment as well as meltwater supply are less vigorous. The general depositional features that can be portrayed for a complete cycle of glacial advance and subsequent retreat include: 
1 Ice-proximal, coarse-grained glaciomarine successions are best developed at or near the maximum ice-front position and characterise the outer glaciated shelf in both ice-stream and inter-stream-dominated areas. Relatively deep marine fans occurred beyond the shelf edge in the axis of ice streams;

2 During ice-sheet recession, ice-sheet collapse in ice-stream-generated troughs resulted in a relatively thin ice-distal glaciomarine sediment cover blanketing the glacial erosion surface. Gradual ice-front recession in adjacent inter-stream areas resulted in well developed fluvio-glacial to fluvial facies;

3 Outwash systems preserved in ice-proximal segments of ice-stream troughs mark transitional conditions showing an evolution from marine-terminating to land-terminating ice fronts in association with a slowing down in the rate of ice-sheet recession;

4 Much of the Hirnantian strata in the middle glaciated shelf essentially record late glacial retreat to interglacial phases. In general, they are finer-grained than strata deposited several hundreds kilometres to the north when the ice-front position was at its maximum.

Several factors have resulted in a complicated glacial record: the stratigraphic superimposition of several, erosionally based, glacial sequences (e.g. Fig. 5B); the possibility that ice streams of successive glacial phases do not necessarily coincide spatially; and Hirnantian glacially induced reactivation of pre-existing basement faults (Ghienne et al., 2003; Turner et al., 2005; Denis et al., submitted). The model presented herein should facilitate a better integration of outcrop and subsurface data, guiding the sequence stratigraphic interpretation of Late Ordovician glacial deposits and other ancient glacial successions. Future research looks forward to the development of a detailed chronostratigraphic framework, which will be the subject of a forthcoming paper.

\section{ACKNOWLEDGEMENTS}

This regional scale study would not have been possible without the combined support of TOTAL, ENI, NOC, REMSA, SONATRACH and TPAO for financial and logistical support necessary for both the fieldwork and writing-up phases of this work. This research was also made possible by the Centre National de la Recherche (CNRS, programme
Eclipse). Daniel Paul Le Heron publishes with the support of the CASP Libya Project Consortium. The manuscript benefited from considerable improvements following the thoughtful reviews of Dag Ottesen and Risto Kumpulainen, and from the editorial support of Mike Hambrey. This is a contribution of EOST (Ecole et Observatoire des Science de la Terre), number 2006.501 - UMR 7517.

\section{REFERENCES}

Abed, M.A., Makhlouf, I.M., Amireh, B.S. and Khalil, B. (1993) Upper Ordovician glacial deposits in southern Jordan. Episodes, 16, 316-328.

Anderson, J.B. and Thomas, M.A. (1991) Marine ice-sheet decoupling as a mechanism for rapid, episodic sealevel change: the record of such events and their influence on sedimentation. Sed. Geol., 70, 87-104.

Anderson, J.B., Shipp, S.S., Lowe, A.L., Wellner, J.S and Mosola, A.B. (2002) The Antarctic Ice Sheet during the Last Glacial Maximum and its subsequent retreat history: a review. Quatern. Sci. Rev., 21, 49-70.

Beuf, S., Biju-Duval, B., De Charpal, O., Rognon P., Gariel, O. and Bennacef, A. (1971) Les grès du Paléozoïque inférieur au Sahara. 'Science et Technique du pétrole', 18, Paris, 464 pp.

Blignault, H.J. (1981) Ice sheet deformation in the Table Mountain Group, Western Cape. Annale Universiteit van Stellenbosch. Series A1 (Geology), 3, 1-66.

Blum, M.D. and Törnqvist, T.E. (2000) Fluvial responses to climate and sea-level change: a review and look forward. Sedimentology, 47 (suppl.), 2-48.

Boote, D.R.D., Clark-Lowes, D.D. and Traut M.W. (1998) Paleozoic petroleum systems of North Africa. In: Petroleum Geology of North Africa (Eds D.S. Macgregor, R.T.J. Moody and D.D. Clark-Lowes), Geol. Soc. London Spec. Publ., 132, 7-68.

Boucot, A.J., Jia-Yu, R., Xu, C. and Scotese, C.R. (2003) Pre-Hirnantian Ashgill climatically warm event in the Mediterranean region. Lethaia, 36, 119-131.

Boulton, G.S. (1990) Sedimentary and sea level changes during glacial cycles and their control on glaciomarine facies architecture. In : Glacimarine environments: processes and sediments (Eds J.A. Dowdeswell \& J.D. Scourse), Geol. Soc. London Spec. Publ., 53, 15-52.

Boulton, G.S. and Clark, C.D. (1990) A highly mobile Laurentide Ice Sheet revealed by satellie images of glacial lineations. Nature, 346, 613-817.

Boulton, G.S., Dongelmans, P., Punkari, M. and Broadgate M. (2001) Palaeoglaciology of an ice sheet through a glacial cycle: the European ice sheet through the Weichselian. Quater. Sci. Rev., 20, 591-625. 
Brenchley, P.J., Carden, G.A., Hints, L., Kaljo, D., Marshall, J.D., Martma, T., Meidla, T. and Nolvak, J. (2003) High-resolution stable isotope stratigraphy of Upper Ordovician sequences: Constraints on the timing of bioevents and environmental changes associated with mass extinction and glaciation. Geol. Soc. Am. Bull., 115, 89-104.

Brookfield, M.E. and Martini, I.P. (1999) Facies architecture and sequence stratigraphy in glacially influenced basins: basic problems and water level/ glacier input-point controls (with an example from the Quaternary of Ontario, Canada). Sed. Geol., 123 183-197.

Canals, M., Urgeles, R., and Calafat, A.M. (2000) Deep sea-floor evidence of past ice streams off the Antarctic Peninsula. Geology, 28, 31-34.

Caputo, M.V. (1998) Ordovician-Silurian glaciations and global sea-level changes. Bull. New York State Mus., $491,15-25$.

Carr, I.D. (2002) Second-order sequence stratigraphy of the Palaeozoic of North Africa. Mar. Petrol. Geol., 25, 259-280.

Clark, C.D. (1993) Mega-scale glacial lineations and cross-cutting ice flow landforms. Earth Surf. Proc. Land., 18, 1-29.

Crossley, R. and McDougall, N. (1998) Lower Palaeozoic reservoirs of North Africa. In: Petroleum Geology of North Africa (Eds D.S. Macgregor, R.T.J. Moody and D.D. Clark-Lowes), Geol. Soc. London Spec. Publ., 132, 157-166.

Dahlgren, K.I.T., Vorren, T.O. and Laberg, J.S. (2002) The role of grounding-line sediment supply in icesheet advances and growth on continental shelves: an example from the mid-Norwegian sector of the Fennoscandian ice sheet during the Saalian and Weichselian. Quatern. Int., 95-96, 25-33.

Dean, W.T. and Monod, O. 1990. Revised stratigraphy and relationships of Lower Palaeozoic rocks, eastern Taurus Mountains, south central Turkey. Geol. Mag., 127, 333-347.

Denis, M., Buoncristiani, J.-F., Konaté, M., Ghienne, J.F. and M. Guiraud. Hirnantian glacial and deglacial record in SW Djado Basin (NE Niger). Submitted to Geodynamica Acta.

Destombes, J. (1968a) Sur la présence d'une discordance générale de ravinement d'âge Ashgill supérieur dans l'Ordovicien terminal de l'Anti-Atlas (Maroc) CR Acad. Sci. Paris, 267, 565-567.

Destombes, J. (1968b) Sur la nature glaciaire des sédiments du groupe du $2^{\mathrm{e}}$ Bani, Ashgill supérieur de l'Anti-Atlas, Maroc. CR Acad. Sci. Paris, 267, D, 684-686.

Destombes, J., Hollart, H. and Willefert, S. (1985) Lower Paleozoic rocks of Morocco. In: Lower Paleozoic Rocks of northwest and west Central Africa (Ed. C.H. Holland) pp. 291-325, John Wiley, New-York.

Deynoux, M. (1980) Les formations glaciaires du Précambrien terminal et de la fin de l'Ordovicien en Afrique de l'ouest. Deux exemples de glaciation d'inlandsis sur une plate-forme stable. Travaux des Laboratoires des Sciences de la Terre, St.Jérome, Marseille, B17, $554 \mathrm{pp}$

Deynoux, M. (1985) Terrestrial or waterlain glacia diamictites? Three case studies from the Late Precambrian and Late Ordovician glacial drifts in West Africa. Palaeogeogr. Palaeoclimatol. Palaeoecol. 51, 97-141.

Deynoux, M. and Ghienne, J.-F. (2004) Late Ordovician glacial pavements revisited - a reappraisal of the origin of striated surfaces.Terra Nova, 16, 95-101.

Deynoux, M. and Ghienne, J.-F. (2005) Late Ordovician glacial pavements revisited - a reappraisal of the origin of striated surfaces. Discussion. Terra Nova, 17 $488-491$

Deynoux, M. and Trompette, R. (1981) Late Ordovician tillites of the Taoudeni Basin, West Africa. In: Earth's pre-Pleistocene glacial record (Eds M.J. Hambrey, W.B. Harland), pp. 89-96, Cambridge University Press. Available on-line via www.aber.ac.uk/glaciology.

Deynoux, M., Ghienne, J.-F. and Manatschal, G. (2000) Stratigraphy and sedimentology of the Upper Ordovician glacially-related deposits of the western Gargaf High, Fezzan, Northern Libya. Unpublished explanatory booklet of the geological map, CNRSEOST, Ecole et Observatoire des Sciences de la Terre Université L. Pasteur, Strasbourg, 41 pp.

Diaz-Martinez, E., Acosta, H., Cardenas J., Carlotta, V. and Rodriguez, R. (2001) Paleozoic diamictites in the Peruvian Altiplano: evidence and tectonic implications. J. S. Am. Earth Sci., 14, 587-592.

Eschard, R., Abdallah, H., Braik, F. and Desaubliaux, G. (2005) The Lower Paleozoic succession in the Tasilli outcrops, Algeria: sedimentology and sequence Stratigraphy. First Break, 23, 27-36

El-ghali, M.A.K. (2005) Depositional environments and sequence stratigraphy of paralic glacial, paraglacial and postglacial Upper Ordovician siliciclastic deposits in the Murzuq Basin, SW Libya. Sed. Geol. 177, 145-173.

Evans, J., Dowdeswell, J.A. and O'Cofaigh, C. (2004) Late Quaternary submarine bedforms and ice-sheet flow in Gerlache Strait and on the adjacent continental shelf, Antartica Peninsula. J. Quatern. Sci., 19, 397-407.

Eyles, C.H., Mory, A.J. and Eyles, N. (2003) Carboniferous-Permian facies and tectonostratigraphic successions of the glacially influenced and rifted Carnarvon Basin, western Australia. Sed. Geol. 155, 63-86. 
Eyles, N. and Januszczak, N. (2004) 'Zipper-rift': a tectonic model for Neoproterozoic glaciations during the breakup of Rodinia after $750 \mathrm{Ma}$, Earth-Sci. Rev. 65, 1-73.

Eyles, N. and McCabe, A.M. (1989) The Late Devensian $(<22000$ BP $)$ Irish Sea Basin: the sedimentary record of a collapsed ice sheet margin. Quatern. Sci. Rev., 8 307-351.

Ghienne, J.-F. (1998) Modalités d'enregistrement d'une glaciation ancienne; exemple de la glaciation finiordovicienne sur la plate-forme nord-gondwanienne en Afrique de l'Ouest. Unpubl. PhD thesis, Université Louis Pasteur, Strasbourg, 407 pp.

Ghienne, J.-F. (2003) Late Ordovician sedimentary environments, glacial cycles, and post-glacial transgression in the Taoudeni Basin, West Africa. Palaeogeogr. Palaeoclimatol., Palaeoecol., 189, 117-145.

Ghienne, J.-F. and Deynoux, M. (1998) Large-scale channel fill structures in Late Ordovician glacial deposits in Mauritania, western Sahara. Sed. Geol., 119, 141-159.

Ghienne, J.-F., Bartier, D., Leone, F. and Loi, A. (2000) Caractérisation des horizons manganésifères de l'Ordovicien supérieur de Sardaigne: relation avec la glaciation fini-Ordovicienne. CR Acad. Sci. Paris, 331, 257-264.

Ghienne, J.F., Deynoux, M., Manatschal, G. and Rubino J.L. (2003) Palaeovalleys and fault-controlled depocenters in the Late Ordovician glacial record of the Murzuq Basin (Central Libya), CR Geosciences, 335, 1091-1100.

Grahn, Y. and Caputo, M.V. (1992) Early Silurian glaciations in Brazil. Palaeogeogr. Palaeoclimatol. Palaeoecol., 99, 9-15.

Hamoumi, N. (1988) La plate-forme ordovicienne du Maroc: dynamique des ensembles sédimentaires. Unpubl. PhD thesis, Université Louis Pasteur, Strasbourg, 237p.

Hiller, N. (1992) The Ordovician System in South Africa: a review. In : Global perspectives on Ordovician geology (Eds Webby, Laurie), 473-485 pp., Balkema Rotterdam.

Hirst, J.P.P., Benbakir, A., Payne, D.F. and Westlake, I.R. (2002) Tunnel Valleys and Density Flow Processes in the upper Ordovician glacial succession, Illizi Basin, Algeria: influence on reservoir quality. Mar. Petrol. Geol., 25, 297-324.

Khoukhi, Y., and Hamoumi, N. (2001) L'Ordovicien de la Méséta orientale (Maroc): stratigraphie génétiquecontrôle géodynamique, climatique et eustatique. Africa Geosci. Rev., 8, 289-302.

Klitzsch, E. (1981) Lower Palaeozoic rocks of Libya, Egypt, and Sudan. In: Lower Palaeozoic of the Middle East, Eastern ans Southern Africa, and Antarctica (Ed. C.H. Holland), pp. 131-163, John Wiley, New York.
Konaté, M, Guiraud, M., Lang, J. and Yahaya, M. (2003) Sedimentation in the Kandi extensional basin (Benin and Niger): fluvial and marine deposits related to the Late Ordovician deglaciation in West Africa. J. Afr. Earth Sci., 36, 185-206.

Kumpulainen, R.A. (2005) Ordovician glaciation in Eritrea and Ethiopia. International Conference on Glacial Sedimentary Processes and Products, University of Wales, Aberystwyth (22-27 august), abstract volume.

Le Heron D. (2004) The development of the Murzuq Basin, SW Libya, during the late Ordovician. Unpubl. $\mathrm{PhD}$ thesis, University of Wales, Aberystwyth.

Le Heron, D., Sutcliffe, O.E., Bourgig, K., Craig, J., Visentin, C. and Whittington, R. (2004) Sedimentary Architecture of Upper Ordovician Tunnel Valleys, Gargaf Arch, Libya: Implications for the Genesis of a Hydrocarbon Reservoir. GeoArabia, 9, 137-160.

Le Heron, D.P., Sutcliffe, O.E., Whittington, R.J. and Craig, J. (2005) The origins of glacially related softsediment deformation structures in Upper Ordovician glaciogenic rocks: implication for ice sheet dynamics. Palaeogeogr., Palaeoclimatol., Palaeoecol., 218, 75-103.

Le Heron, D., Ghienne, J.-F., El Houicha, M., Khoukhi, Y. and Rubino, J.-L. (in press, a) Maximum extent of ice sheets in Morocco during the Late Ordovician glaciation. In: Lower Palaeozoic Palaeogeography and Palaeoclimate (Eds Munnecke, A. \& Servais, T.) Palaeogeogr. Palaeoclimatol. Palaeoecol.

Le Heron, D., Craig, J., Sutcliffe, O., Whittington, R. (in press, b) Ordovician glaciogenic reservoir heterogeneity: an example from the Murzuq Basin Libya. Mar. Petrol. Geol.

Legrand, P. (1974) Essai sur la paléogéographie de l'Ordovicien du sahara algérien. Compagnie Française des Pétroles, Notes et Mémoires, 11, 121-138.

Legrand, P. (1985) Lower Palaeozoic rocks of Algeria. In: Lower Palaeozoic of north-western and west-central Africa (Ed. C.H. Holland), pp. 5-89, John Wiley, New-York.

Legrand, P. (1993) Graptolites d'âge ashgillien dans la région de Chirfa (Djado, République du Niger). Bull. Centres Rech. Explor.-Prod. Elf Aquitaine, 17, 435-442.

Legrand, P. (2003) Paléogeographie du Sahara algérien à l'Ordovicien terminal et au Silurien inférieur. Bull. Soc. Geol. Fr., 174, 19-32.

Leone, F., Loi, A. and Pillola G.L. (1995) The post Sardic Ordovician sequence in SW Sardinia. In: $6^{\text {th }}$ Palaeobenthos International Symposium (Ed. A. Cherchi), Guide book, pp. 81-108, Cagliari University.

Lønne, I. (1995) Sedimentary facies and depositional architecture of ice-contact glaciomarine systems. Sed. Geol., 98, 13-43. 
Lønne, I., Nemec, W., Blikra, L.H. and Lauritsen, T. (2001) Sedimentary architecture and dynamic stratigraphy of a marine ice-contact system. J. Sed. Petrol., 71, 922-943.

Lüning, S., Craig. J., Loydell, D.K., Storch, P. and Fitches, B. (2000) Lower Silurian 'hot shales' in North Africa and Arabia: regional distribution and depositional model. Earth-Sci. Rev., 49, 121-200.

Martinez, M. (1998) Late Ordovician glacial deposits of northwest Argentina: new evidence from the Mecoyita Formation, Santa Victoria Range. J. Afr. Earth Sci., 27, supplement 1, 136-137.

Massa, D. (1988) Paléozoïque de Libye occidentale. Stratigraphie et Paléogéographie. Unpublish. Thèse d'Etat Université de Nice, 514 pp.

McDougall, N. and Martin, M. (2000) Facies models and sequence stratigraphy of Upper Ordovician outcrops in the Murzuq Basin, SW Libya. In: Geological Exploration in Murzuq Basin (Eds M.A. Sola and D. Worsley), pp. 223-236, Elsevier Science.

McGillivray, G.J. and Husseini, M. (1992) The Paleozoic petroleum geology of Central Saudi Arabia. AAPG Bull., 76, 1473-1490.

McLure, H.A. (1978) Early Paleozoic glaciation in Arabia Palaeogeogr., Palaeoclimatol., Palaeoecol., 25, 315-326.

Monod, O., Kozlu, H., Ghienne, J-F., Dean, W.T. Günay, Y., Le Hérissé, A., Paris, F. and Robardet, M. (2003) Late Ordovician glaciation in southern Turkey. Terra Nova, 15, 249-257.

Moreau, J. (2005) Architecture stratigraphique et dynamique des dépôts glaciaires ordoviciens du Bassin de Murzuk (Libye). Unpubl. PhD thesis, Université Louis Pasteur, Strasbourg.

Moreau, J., Ghienne, J.-F., Le Heron, D., Rubino, J.-L. and Deynoux, M. (2005) A 440 Ma old ice stream in North Africa. Geology, 33, 753-756.

Ottesen, D., Dowdeswell, J.A. and Rise, L. (2005) Submarine landforms and the reconstruction of fastflowing ice streams within a large Quaternary ice sheet: The 2500-km-long Norwegian-Svalbard margin $\left(57^{\circ}-80^{\circ} \mathrm{N}\right)$. Geol. Soc. Am. Bull., 117, 1033-1050.

Ouanaimi, H. (1998) Le passage Ordovicien-Silurien à Tizi n'Tichka (Haut-Atlas, Maroc): variations du niveau marin, CR Acad. Sci. Paris, 326, 65-70.

Oulebsir, L. and Paris, F. (1995) Chitinozoaires ordoviciens du Sahara algérien: biostratigraphie et affinités paléogéographiques. Rev. Palaeobot. Palynol., 86, 49-68.

Paris, F., Elaouad-Debbaj, Z., Jaglin, J.C., Massa, D. and Oulebsir, L. (1995) Chitinozoans and Late Ordovician glacial events on Gondwana. In: Ordovician Odyssey (Eds J.D. Cooper, M.L. Droser and S Finney), pp. 171-176, Short papers for the seventh international symposium on the Ordovician System, SEPM, Fullerton, California.
Paris, F., Deynoux, M. and Ghienne, J.-F. (1998) Chitinozoaires de la limite Ordovicien-Silurien en Mauritanie. CR Acad. Sci. Paris, 326, 499-504.

Powell, R.D. (1990) Sedimentary processes at grounding line fans and their growth to ice-contact deltas. In: Glacimarine environments: processes and sediments (Eds J.A. Dowdeswell and J.D. Scourse), Geol. Soc London Spec. Publ., 53, 53-77.

Powell, R.D., Khalil Moh'd, B. and Masri, A. (1994) Late Ordovician-Early Silurian glaciofluvial deposits preserved in palaeovalleys in South Jordan. Sed. Geol., 89, 303-314.

Proust, J.-N. and Deynoux, M. (1993) Marine to non marine sequence architecture of an intracratonic glacially related basin. Late Proterozoic of the West African platform in western Mali. In: Earth's Glacial Record (Eds M. Deynoux, J.MG. Miller, E.W. Domack, N. Eyles, I.J. Fairchild and G.M. Young), pp. 241259, Cambridge University Press.

Robardet, M. and Doré, F. (1988) The Late Ordovician diamictic formations from southwestern Europe: North-Gondwana glaciomarine deposits. Palaeogeogr. Palaeoclimatol. Palaeoecol., 66, 19-31.

Ross, J.R.P. and Ross C.A. (1992) Ordovician sea-level fluctuations. In: Global perspectives on Ordovician geology (Eds B.D. Webby and J.R. Laurie), pp. 327-336 Balkema, Rotterdam.

Russell, H.A.J. and Arnott, R.W.C. (2003) Hydraulic-jump and hyperconcentrated-flow deposits of a glacigenic subaqueous fan: Oak Ridges Moraines, southern Ontario, Canada. J. Sed. Res., 73, 887-905.

Russell, H.A.J., Arnott, R.W.C. and Sharpe, D.R. (2003) Evidence for rapid sedimentation in a tunne channel, Oak Ridges Moraine, southern Ontario, Canada. Sed. Geol., 160, 33-55.

Saltzman, M.R. and Young, S.A. (2005) Long-lived glaciation in the Late Ordovician? Isotopic and sequence-stratigraphic evidence from western Laurentia. Geology, 33, 109-112.

Senalp M. and Al-Laboun A. (2000) New evidence on the Late Ordovician Glaciation in Central Saudi Arabia. Saudi Aramco Journal of Technology, 1-40 (Spring).

Smart, J. (2000) Seismic expressions of depositional processes in the upper Ordovician succession of the Murzuq Basin, SW Libya. In: Symposium on Geological Exploration in Murzuq Basin (Eds M.A. Sola and D. Worsley), pp. 397-415, Elsevier, Amsterdam.

Stampfli, G.M. and Borel G.D. (2002) A tectonic model for the Paleozoic and Mesozoic constrained by dynamic plate boundaries and restored synthetic oceanic isochrones. Earth Planet. Sci. Lett., 196, 17-33.

Stokes, C.R. and Clark, C.D. (2001). Palaeo-ice streams. Quatern. Sci. Rev., 20, 1437-1457. 
Storch, P. and Leone, F. (2003) Occurrence of the late Ordovician (Hirnantian) graptolite Normalograptus ojuensis (Koren \& Mikhaylova, 1980) in south western Sardinia, Italy. Bol. Della Soc. Paleont. Ital. 42, 31-38.

Sutcliffe, O.E., Dowdeswell, J.A., Whittington, R.J., Theron, J.N., and Craig, J. (2000) Calibrating the Late Ordovician glaciation and mass extinction by the eccentricity cycles of Earth's orbit. Geology, 28, 967-970.

Sutcliffe, O.E., Harper, D.A.T., Aït Salem, A., Whittington, R.J. and Craig, J. (2001) The development of an atypical Hirnantia-brachiopod Fauna and the onset of glaciation in the late Ordovician of Gondwana Trans. Roy. Soc. Edinb. Earth Sci., 92, 1-14.

Underwood, C.J., Deynoux, M. and Ghienne, J.-F. (1998) High palaeolatitude recovery of graptolite faunas after the Hirnantian (top Ordovician) extinction event. Palaeogeogr. Palaeoclimatol. Palaeoecol., 142 91-105.

Turner, B.R., Makhlouf, I.M. and Armstrong, H.A. (2005) Late Ordovician (Ashgillian) glacial deposits in southern Jordan. Sed. Geol., 181, 73-91.
Vaslet, D. (1990) Upper Ordovician glacial deposits in Saudi Arabia. Episodes, 13, 147-161.

Vecoli, M. and Le Hérissé, A. (2004) Biostratigraphy, taxonomic diversity and patterns of morphological evolution of Ordovician acritarchs (organic-walled microphytoplankton) from the northern Gondwana margin in relation to palaeoclimatic and palaeogeographic changes. Earth-Sci. Rev., 67, 267-311.

Vorren, T.O. and Laberg, J.S. (1997) Trough mouth fans - Palaeoclimate and ice-sheet monitors. Quatern. Sci. Rev., 16, 865-881.

Webby, B.D., Cooper, R.A., Bergström, S.M. and Paris, F. (2004) Stratigraphic framework and time slices. In: The Great Ordovician Diversification Event (Eds B.D. Webby, F. Paris, M. Droser and I. Percival), pp. 41-47, Columbia University Press, New York.

Young, G.M., Minter W.E.L. and Theron, J.N. (2004) Geochemistry and palaeogeography of upper Ordovician glaciogenic sedimentary rocks in the Table Mountain Group, South Africa, Palaeogeogr. Palaeoclimatol., Palaeoecol., 214, 323-345. 
GSP_4_C17.qxd 9/18/07 17:05 Page 320

$\varnothing$

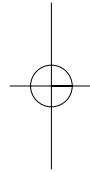




\section{Author Query Form}

Book title: Glacial Sedimentary Processes and Products

Chapter title: The Late Ordovician glacial sedimentary system of the North Gondwana platform

\begin{tabular}{|c|l|l|}
\hline $\begin{array}{l}\text { Query } \\
\text { Refs. }\end{array}$ & Query & Remarks \\
\hline 1 & $\begin{array}{l}\text { DANIEL PAUL LE HERON has his present address added in } \\
\text { affiliations line - should this be kept in? }\end{array}$ & \\
\hline
\end{tabular}

